\title{
Advances in the study of cancer metastasis and calcium signaling as potential therapeutic targets
}

\author{
Chaochu Cui ${ }^{1+}$, , Yongxi Zhang ${ }^{2 \dagger}$, Gang Liu $^{1}$, Shuhong Zhang ${ }^{1}$, Jinghang Zhang ${ }^{3}$, Xianwei Wang ${ }^{1 *}$ \\ ${ }^{1}$ Henan Key Laboratory of Medical Tissue Regeneration, College of Basic Medical Sciences, Xinxiang Medical University, Xinxiang \\ 453003, Henan, China \\ ${ }^{2}$ Department of Oncology, The Third Affiliated Hospital of Xinxiang Medical University, Xinxiang 453003, Henan, China \\ ${ }^{3}$ Department of Pathology, The First Affiliated Hospital of Xinxiang Medical University, Xinxiang 453003, Henan, China
}

${ }^{\dagger}$ These authors contributed equally to this work.

*Correspondence: Xianwei Wang, Henan Key Laboratory of Medical Tissue Regeneration, College of Basic Medical Sciences, Xinxiang Medical University, Xinxiang, 453003, Henan, China. Wangxianwei1116@126.com

Academic Editor: Zui Pan, The University of Texas at Arlington, USA

Received: March 01, 2021 Accepted: April 21, 2021 Published: June 28, 2021

Cite this article: Cui CC, Zhang YX, Liu G, Zhang SH, Zhang JH, Wang XW. Advances in the study of cancer metastasis and calcium signaling as potential therapeutic targets. Explor Target Antitumor Ther. 2021;2:266-91. https://doi.org/10.37349/ etat.2021.00046

\begin{abstract}
Metastasis is still the primary cause of cancer-related mortality. However, the underlying mechanisms of cancer metastasis are not yet fully understood. Currently, the epithelial-mesenchymal transition, metabolic remodeling, cancer cell intercommunication and the tumor microenvironment including diverse stromal cells, are reported to affect the metastatic process of cancer cells. Calcium ions $\left(\mathrm{Ca}^{2+}\right)$ are ubiquitous second messengers that manipulate cancer metastasis by affecting signaling pathways. Diverse transporter/pump/ channel-mediated $\mathrm{Ca}^{2+}$ currents form $\mathrm{Ca}^{2+}$ oscillations that can be decoded by $\mathrm{Ca}^{2+}$-binding proteins, which are promising prognostic biomarkers and therapeutic targets of cancer metastasis. This paper presents a review of the advances in research on the mechanisms underlying cancer metastasis and the roles of $\mathrm{Ca}^{2+}-$ related signals in these events.
\end{abstract}

\section{Keywords}

Calcium channel, cancer metastasis, epithelial-mesenchymal transition, tumor microenvironment, immunosurveillance, metastatic colonization

\section{Introduction}

Cancer metastasis is a process in which cancer cells spread from the primary site to secondary sites. Cancer metastasis is affected by chemoattractants [1], the tumor microenvironment (TME) [2], tissue topography [3], the epithelial-mesenchymal transition (EMT), metabolic remodeling [4, 5], communication between cancer cells [6], etc. Despite the significant achievements in the diagnosis of cancer and therapy interventions, cancerrelated death remains an urgent problem worldwide, with cancer metastasis being the major challenge [7-9]. Firstly, metastatic cancer cells can seed new foci and grow into new tumors in target organs, even after

(C) The Author(s) 2021. This is an Open Access article licensed under a Creative Commons Attribution 4.0 International License (https://creativecommons.org/licenses/by/4.0/), which permits unrestricted use, sharing, adaptation, distribution and reproduction in any medium or format, for any purpose, even commercially, as long as you give appropriate credit to the original author(s) and the source, provide a link to the Creative Commons license, and indicate if changes were made. 
excision of the primary tumor due to early dissemination and seeded metastasis [10]. Secondly, metastatic cancer cells exhibit enhanced survival ability and resistance to most chemo- and radio-therapy that are highly efficient in certain primary nonmetastatic cancer cells [11,12].

Ubiquitous calcium ions $\left(\mathrm{Ca}^{2+}\right)$ are major second messengers and are critical to diverse physiological cellular events. Remodeling $\mathrm{Ca}^{2+}$ signals have been demonstrated to be essential in numerous diseases, including cancer [13-15]. In addition to chemoresistance, $\mathrm{Ca}^{2+}$ is also of importance in cancer metastasis, as proven decades ago $[16,17]$. For example, $\mathrm{Ca}^{2+}$ is essential for focal adhesion turnover by regulating tyrosine kinase focal adhesion kinase (FAK) [13]. Focal adhesion turnover is critical in cycles of adhesion and detachment. It forms the traction points through which a cell moves forward and retracts the rear [18]. The intracellular distribution of $\mathrm{Ca}^{2+}$ is delicately balanced by several channel/pump/transporter families, including dozens of proteins located on the plasma membrane, endoplasmic reticulum (ER), mitochondria, and lysosomes. The signals of regional $\mathrm{Ca}^{2+}$ oscillations are decoded by numerous $\mathrm{Ca}^{2+}$-binding proteins with different distributions and affinities for $\mathrm{Ca}^{2+}$, further inducing a signaling cascade to regulate cell activity [17]. With the incessant discoveries of metastatic mechanisms, $\mathrm{Ca}^{2+}$-binding proteins, and $\mathrm{Ca}^{2+}$ channels/pumps/ transporters, the roles of $\mathrm{Ca}^{2+}$ signaling in cancer metastasis have been increasingly revealed, serving as promising biomarkers for the prognosis and therapeutic targets of cancer metastasis.

\section{Basic process of tumor metastasis}

Solid tumor metastasis is a complicated multistep and inefficient process. It includes separation and migration from primary tumors, invasion of local tissues, intravasation into blood or lymphatic vessels for transmission, extravasation into distant tissues and growth into macroscopic tumors [9]. Both cell-autonomous and noncell-autonomous mechanisms are crucial for successful cancer metastasis [19]. The plasticity of cancer cells, including their morphology and metabolism, is one major reason for successful cancer metastasis. For example, cells usually require the formation of lamellipodia at their leading edge, cycles of focal adhesion turnover, cell body contraction, and tail retraction [20-22]. Furthermore, intervention stresses, including radio- [23] and chemo-therapy [11], can also cause cancer metastasis.

The "amoeboid" form of invasion means that individual cancer cells with morphological plasticity can pass through existing interstices in the extracellular matrix (ECM). This movement differs from that of collective and mesenchymal invasion, both of which are dependent on the ability of the cancer cells to clear a path [24, 25]. Collective metastasis involves clusters of cancer cells invading adjacent tissues and spreading to distal organs [26]. Some studies demonstrate that multicellular tumor cell clusters, not single cell, present tumor invasive fronts, systemic circulation, and colonization of distant organs. Within these clusters, cancer cells may communicate and exchange signaling factors to promote metastasis [6,27]. Mesenchymal invasion through the EMT program is the best characterized form of metastasis. In this process, cancer cells remodel the pattern of cytoskeletal proteins and adhesion molecules, and they further acquire stem features. E-cadherin, a classical and critical adhesion molecule, is lost in EMT. This loss favors cancer cells escape from endothelial cell (EC) sheets and promotes metastasis [20].

Tumor cells penetrating tissues through confining spaces must undergo extensive deformation, including its nucleus. However, this deformation can cause localized loss of nuclear envelope (NE) integrity and DNA damage, which may be a weakness of metastatic cancer cells [28]. Cancer cells exhibit increased chromatin accessibility during metastatic progression, which enhances prometastatic gene expression and promotes the metastatic ability of cancer cells [29]. Synonymous mutations may specifically regulate the expression of proteins that favor metastasis. Upregulation of tRNA ${ }^{\text {Glu } U U C ~ a n d ~ t R N A ~}{ }^{\mathrm{Arg}} \mathrm{CCG}$ promotes breast

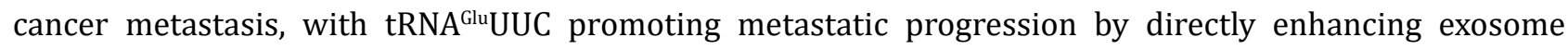
component exosome component 2 (EXOSC2) and glutamate receptor interacting protein 1 (GRIP1) associated protein 1 (GRIPAP1) protein expression [30]. The expression of genes coding ribosomal proteins (RPs) and regulators of translation is also increased in breast circulating tumor cells (CTCs). RPL15 (eL15), a component of the large ribosomal subunit, increases the translation rate of other RPs and cell cycle regulators, leading to breast cancer cells metastatic growth in multiple organs [31]. 


\section{Mechanisms of cancer cells metastasis}

Separation and migration from primary tumors

Dissemination and metastasis may occur at an early tumor stage or even precede primary tumor formation [10, 32, 33]. One force that drives cells disseminating from tumors is the repulsive effect, which is also called contact inhibition of locomotion (CIL). CIL suppresses forward locomotion during cell-cell contact and redirects cell motility, which can enhance cancer invasiveness by favoring redirection of cancer cells into the stromal environment [34].

In primary tumor sites, cancer cells recruit myeloid-derived suppressor cells (MDSCs) to induce the acquisition of the EMT/stemness phenotype in cancer cells at the invasive cancer edge [35]. Ephrin type-A receptor 2 (EphA2) promotes membrane-anchored membrane type-1 matrix metalloproteinase (MT1-MMP) expression in invasive breast cancer cells. MT1-MMP in turn cleaves EphA2 and activates the EphA2/Src/ RhoA axis, which induces actomyosin contractility and cell junction disassembly. These changes ultimately induce cell transition to rounded morphology, cell-cell repulsion, dissemination, and single-cell invasion [36].

\section{Crosstalk between cancer cells and circulatory systems}

For seeding and growth at the secondary sites, cancer cells usually infiltrate into circulatory systems such as lymphatic and/or vascular vessels. CTCs are essential for distant metastasis of cancer, but only a small subset of CTCs can generate metastatic tumors [37-39]. This is because circulatory systems and distant organs are usually not hospitable to cancer cells, due to oxidative stress, anoikis, and the immunosurveillance system [40-42]. Melanoma cells with high metastatic ability preferentially upregulate monocarboxylate transporter 1 (MCT1) to consume more lactate, and cells with high MCT1 expression are more prominent in blood than in primary tumors. Selective inhibition of MCT1 does not affect the migration or invasion of melanoma cells or primary tumor growth, but it significantly reduces the frequency of circulating melanoma cells in the blood and cancer metastasis. This outcome is the result of MCT1 promoting cell survival during metastasis, partly by decreasing oxidative stress [37, 43]. Internalized $\beta 1$-integrin localizes to autophagyrelated endomembranes and triggers c-Met-sustained prosurvival in an adhesion-independent manner, preventing detached cancer cells from undergoing anoikis. This mechanism gives cancer cells sufficient time to land successfully [44].

Crosstalk between cancer cells and the lymphatic system

Lymphatic and vascular systems are the major access for cancer cells destined for distal metastasis by increased permeability [45], lymphoid hyperplasia [46], or angiogenesis [47]. Interestingly, cancer cells preferentially metastasize regionally through the lymphatic system before metastasizing to distal organs via blood. This outcome is partially the result of lymph fluid containing a high level of oleic acid, which protects cancer cells from ferroptosis in an acyl-coenzyme A synthetase long-chain family member 3 (ACSL3)-dependent manner [42]. Vascular endothelial growth factor-D (VEGF-D) produced by cancer cells inhibits prostaglandin degradation and results in the dilation of collecting lymphatic vessels, which ultimately promotes cancer metastasis [48]. Melanoma cells secrete midkine to induce distal premetastatic niches by driving lymphangiogenesis in a paracrine-dependent manner [46]. Cancer cells also produce interleukin-6 (IL-6) to activate signal transducer and activator of transcription 3 (STAT3) to induce hypoxia-inducible factor1 alpha (HIF-1 $\alpha$ ), VEGF, and C-C motif ligand (CCL) 5 expression in lymphatic ECs (LECs) within premetastatic niches to promote metastasis [49]. IL-10 derived from tumor-associated macrophages (TAMs) increases the expression of specificity protein 1 (Sp1) in LECs in a hypoxic TME. This Sp1 expression in turn induces the production of CCL1 in activated LECs to recruit TAMs and cancer cells, resulting in lymphatic vessels encapsulated by TAMs (LVEM) to promote cancer metastasis [50].

\section{Crosstalk between cancer cells and the vascular system}

Patrolling monocytes in blood possess early interactions with metastatic cancer cells. They can scavenge cancer cells from the vasculature and promote natural killer (NK) cell recruitment and activation [41]. Platelet-secreted transforming growth factor $\beta$ (TGF $\beta$ ) is necessary but not sufficient for the extravasation and subsequent metastatic niche formation of CTCs. Furthermore, platelets directly interacting with CTCs 
activate nuclear factor-kappa B (NF- $\mathrm{BB}$ ) signals and induce the EMT in cancer cells, which in cooperation with TGF $\beta$ signaling facilitates metastasis [51, 52].

Cancer cells can recruit ECs and initiate angiogenesis [47]. Chemotherapy can also enhance angiogenesis to promote metastasis [53]. In addition to recruiting myeloid cells, tumor cell-derived CCL2 activates C-C motif receptor (CCR) 2 on ECs, inducing vascular permeability and subsequent cancer cell extravasation [45]. In brain cancer metastasis, melanoma cells increase blood-brain barrier (BBB) permeability [54]. Amyloid precursor proteins from cancer cells induce endothelial necroptosis via death receptor 6 (DR6) on ECs to enhance extravasation [55]. The intracellular domain of Notch1 receptors (N1ICDs) are activated in ECs in both primary tumors and premetastatic niches. N1ICDs ultimately induce EC senescence, neutrophil infiltration, tumor cells adhesion to the endothelium, intravasation, and metastasis [56].

Some cancer cells preferentially attach to the vascular network and migrate through endothelial layers by adopting a spindle-shaped morphology. They invaginate into the endothelial network by forming nanoscale membrane bridges between metastatic cancer cells and ECs to transfer signaling factors. This signaling leads to a cancer cell-induced pathological endothelium and metastatic foci in vivo [57].

Metastatic cancer cells that intravasate into the vasculature secrete Serpin Family E Member 2 (SERPINE2) and secretory leukocyte protease inhibitor (SLPI) to promote metastasis. These factors are required to program cancer cells for vascular mimicry, a program in which cells differentiate into endothelial-like cells and form extracellular-matrix-rich tubular structures to carry blood from the vasculature to hypoxic regions of the tumor [58]. A novel theory explaining cancer spread is called angiotropic migration, which is derived from a program initially involved in embryogenesis. In cancer metastasis, cancer cells attach to the abluminal surfaces of blood vessels and spread via continuous migration, competing with pericytes and replacing them, i.e. pericyte mimicry. This manner of spreading has been demonstrated in several types of cancer, including melanoma, glioma, colon, and breast cancer [59].

\section{Metastatic colonization}

Metastatic cancer cells at secondary sites may die, be cleared, grow into macrometastases, or remain dormant only to grow into micrometastases decades after seeding [9, 32]. The reasons for the dormancy of cancer cells may be attributed to unfit proliferation conditions, such as nutrient starvation or inhibition by the immune system, or they may acquire suppressive factors from the primary tumor, or lack the ability to activate angiogenesis [60]. For example, breast cancer cells can directly engulf mesenchymal stem cells to enhance their prosurvival ability, but they then turn dormant [61].

Bone marrow-derived myeloid cells can become central nervous system (CNS) myeloid-like cells once they translocate to the brain. CNS-native myeloid cells display downregulation of CX3CR1, which enhances C-X-C motif (CXC) chemokine ligand (CXCL)10 signaling to foster an immunosuppressive niche and promote brain metastasis of cancer cells [62]. In addition, astrogliosis and neuroinflammation are instigated in the early stage of metastasis to promote the initial growth of metastatic melanoma cells in the brain [54].

\section{Hospitable destinations: the liver and lung}

Thrombopoietin-mediated activation of lysine degradation reduces oxidative stress via the Lys-Glu pathway and induces c-myc to recruit chromatin modifiers to regulate gene expression in cancer cells. This process enhances the production of acetyl-CoA and is essential for thrombopoietin-binding receptor-positive colorectal cancer cells spread in liver metastasis. The liver is the major organ producing thrombopoietin, which is a niche component that is critical for cancer cell colonization. Thrombopoietin production is probably why the liver is a preferred target organ of metastatic cancer cells [63].

The lung with high oxygen is also a favored target of metastatic cancer cells. Prolyl hydroxylase (PHD), an oxygen sensor, is intrinsically and functionally redundant in lung $\mathrm{T}$ lymphocytes. PHD inhibits HIF accumulation to suppress glycolytic metabolism. This suppression leads to a pulmonary T helper (Th)-1 cell response, promotes $\mathrm{CD} 4^{+}$-regulatory $\mathrm{T}$ cell (Treg) induction, and restrains CD8 ${ }^{+} \mathrm{T}$ cell effector function, ultimately resulting in an immunosuppressive microenvironment that gives license to tumor colonization at the lung [64]. 


\section{Adaptation to the target organ microenvironment}

Efficiently taking advantage of the homing organ microenvironment is especially important for successful metastasis of cancer cells. In addition to sensing the level of Rac activity in adjacent cells to organize individual cells in cell clusters, Rab11b is necessary for metastatic breast cancer cells to adapt to the brain microenvironment, since Rab11b manipulates the expression of critical proteins at the cancer cell surface. For example, Rab11b regulates the recycling of integrin $\beta 1$, which allows cancer cells to engage with the brain ECM efficiently to activate mechanotransduction signaling $[65,66]$. To adapt to hepatic hypoxia, metastatic colon cancer cells (CRCs) import extracellular phosphocreatine, which is mediated by the creatine transporter SLC6A8, to generate intracellular ATP [67]. Ovarian cancer cells that metastasize to the omentum utilize fatty acids produced by adipocytes to meet their energic requirement via upregulating fatty acid-binding protein (FABP) 4 [4].

Brain astrocytes secrete exosomes containing miRNAs that inhibit phosphatase and tensin homolog (PTEN) expression in metastatic cancer cells. This process is reversible since cancer cells restore PTEN expression after they leave the brain. Loss of PTEN in cancer cells leads to the upregulated secretion of the chemokine CCL2, which recruits ionized calcium binding adaptor molecule 1 (IBA1)-expressing myeloid cells. This process ultimately promotes the outgrowth of brain metastatic tumor cells via enhanced proliferation and attenuated apoptosis [68].

Preparation and inducing transformation of the soil

Most cancer cells are poorly adapted to the microenvironment of the premetastatic tissue where they land, at least initially. The transcriptional and proteomic diversity between micrometastatic and primary tumor cells is universal. Cancer cells that have undergone the EMT may undergo the mesenchymalepithelial transition (MET) to restore efficient proliferation ability, which can be induced by granulocytic MDSCs (gMDSCs) that are recruited by cancer cells at metastatic sites [35, 69, 70]. Cancer cells can inhibit Th-1 polarization or decrease CD4+ $\mathrm{T}$ cell levels in the metastatic TME to favor cancer cells survival $[7,71]$.

Cancer cells may remodel the ECM to form a premetastatic niche by secreting extracellular vesicles (EVs) in advance to escape dormancy at metastatic sites [72-74]. Tumor cells can prepare the premetastatic niche by secreting exosomes, which can be taken up by specific resident cells at their predicted destination. For example, the secretome of hypoxic primary cancer contains lysyl oxidase, which facilitates osteolytic lesion formation to promote CTCs colonization and metastasis formation in bone [75]. Exosomes from lung-, liverand brain-tropic tumor cells fuse preferentially with lung fibroblasts and epithelial cells, liver Kupffer cells, and brain ECs, respectively. These exosomes determine the target organ of cancer cells; for example, exosomes from lung-tropic model cells redirected the metastasis of bone-tropic tumor cells because they transport specific integrins to the distal organ, where they activate Src and upregulate the expression of promigratory and proinflammatory S100 molecules. In addition, $\alpha 6 \beta 4$ and $\alpha 6 \beta 1$ are associated with lung metastasis, while $\alpha v \beta 5$ is linked to liver metastasis [76].

Once CTCs arrive at the target organ, they lodge in capillaries and shed microscale blebs with diameters of $\sim 5 \mu \mathrm{m}$ into the vasculature. Most of these microparticles preferentially attach to the vasculature or independently migrate along the inner walls of vessels instead of dispersing in the blood flow. These microparticles are ingested by they recruit waves of distinct myeloid cell subsets. The cells in the early waves facilitate the survival of CTCs, while a small population of resident conventional dendritic cells in the last waves interact with CTCs and exert antimetastatic effects [77].

Phosphorylation of adenosine monophosphate (AMP)-activated protein kinase (AMPK) $\alpha$ is upregulated in metastatic tumors. Deletion of AMPK $\alpha$ impairs lung metastasis without affecting primary tumor growth. This effect is due to the ability of AMPK to phosphorylate the catalytic $\alpha$ subunit of PDHc (PDHA) to drive the tricarboxylic acid (TCA) cycle, which renders cancer cells resistant to metabolic and oxidative stress [78]. Fructose can promote metastasis of colon and breast cancers [79, 80]. CRCs that metastasize to the liver display upregulation of aldolase B (ALDOB). ALDOB promotes fructose metabolism, which is essential for the growth of CRCs in the liver. More importantly, CRC cells that are directly injected into the liver also display 
an increase in ALDOB. This finding directly demonstrates that reprograming metabolism occurs both at the premetastatic stage and when cancer cells land on new organs [79].

\section{Crosstalk between cancer cells and the TME}

Communications between cancer cells and the TME are pivotal in cancer metastasis. The TME, including the ECM, bacteria, fibroblasts, mesenchymal stem cells, and macrophages, is essential for the phenotype of tumor $[12,81,82]$. Several types of cells derived from bone marrow, including macrophages, neutrophils, mast cells, and myeloid progenitors, are involved in pathological angiogenesis. In addition to reducing the effect of drugs targeting vasculature EC signals, they can facilitate local invasion [9, 83]. Cancer cells recruit gMDSCs and monocytic MDSCs (mMDSCs) for infiltration. The mMDSCs promote cancer cells dissemination by inducing EMT/stemness, while gMDSCs promote metastatic growth by reverting EMT/stemness [35]. Bacteria were firstly detected in human tumors more than 100 years ago. Intracellular bacteria are present in both cancer and immune cells [84]. Exosomes from those bacteria deliver factors such as IL-8 to noninfected cancer cells to increase the metastasis rate [1].

\section{Cancer-associated fibroblasts}

Cancer-associated fibroblasts (CAFs) can produce exosomes that transfer bioactive factors such as miRNA to induce the EMT and stemness of cancer cells [12]. Cancer cells undergoing the EMT preferentially localize to the leading edge of primary tumors, resulting in their positioning adjacent to the stroma, which includes CAFs [85]. EphA-mediated CIL promotes the formation of disseminated tumor cells (DTCs) [36, 86]. Furthermore, EphB2-induced EphB3/EphB4/Cdc42 signaling tightens the interaction between DTCs and CAFs, allowing for invasiveness and metastasis [86]. CAFs generate tracks to facilitate collective invasion by remodeling protease- and force-mediated matrix [2]. CAFs produce ligands that correspond to receptors expressed by cancer cells to promote metastasis [85]. For example, TGF $\beta$ derived from cancer cells enhances the secretion of IL-11 in CAFs. IL-11 in turn activates GP130/STAT3 in cancer cells to initiate metastasis [85]. CAFs can act as damage-associated molecular pattern (DAMP) sensors. Activation of nucleotide-binding domain and leucine-rich repeat containing (NLR) family pyrin domain containing 3 (NLRP3) signaling in CAFs increases the production of IL-1 $\beta$. IL-1 $\beta$ facilitates breast cancer cells metastasis in the lung by modulating the immune cell milieu at the metastatic site and the expression of adhesion molecules [87].

\section{TAMs}

TAMs secrete TGF $\beta 1$, EGF and matrix-degrading enzymes, including $\mathrm{Ca}^{2+}$-dependent MMPs [88, 89]. Metastatic double-negative prostate cancer (DNPC) cells express high level of CCL2 to recruit M2-like TAMs and Tregs, which enhances metastasis initiation in conjunction with immunosuppression and neoangiogenesis [39]. In addition to promoting angiogenesis, angiotensin (Ang) II-activated ECs also produce CCL2. This production recruits additional CCR2 ${ }^{+}$macrophages to infiltrate tumors, which ultimately promotes metastasis [90]. TAMs are negatively correlated with the survival of hepatocellular carcinoma (HCC) patients, since these TAMs secrete TGF $\beta 1$ to induce the EMT and confer higher invasiveness in cancer cells [91]. Interestingly, cancer cells can produce a series of factors, including IL-4, colony stimulating factor-1 (CSF-1) and platelet-derived growth factor-BB (PDGF-BB), directly or indirectly in a pericyte- and fibroblast-derived IL-33-dependent manner to recruit TAMs, and thus promote metastasis [9, 92].

\section{Mesenchymal stem cells}

Mesenchymal stem cells (MSCs) are usually involved in maintaining tissue architecture and mediating pathological stromal responses during injury repair. Interestingly, cancer cells produce soluble factors that recruit MSCs from the bone marrow to the primary tumor site. Intratumor MSCs secrete CCL5 to stimulate the invasive behavior of cancer cells [93, 94]. Moreover, CXCL16 produced by cancer cells binds to CXC receptor (CXCR) 6 on MSCs, leading to the transition of MSCs to CAFs and the production of CXCL12. CXCL12 further binds to CXCR4 on cancer cells, inducing EMT and promoting metastasis [95]. In addition to TAMs, a small population of breast cancer cells can engulf MSCs to promote self-renewal, mesenchyme-like and metastatic properties $[94,96]$. 


\section{Communications between cancer cells}

Communications between cancer cells depend on direct interactions or EVs, including exosomes, to transfer biomolecules such as proteins and nucleic acids [97]. Cancer cells undergoing EMT can produce the EMTinducing transcription factor Six1 to promote the metastasis of non-EMT cancer cells [98]. Collective metastasis is also dependent on the EMT. Clusters of cancer cells internalize $\mathrm{N}$-cadherin, which induces the acquisition of only a partial mesenchymal phenotype characterized by an increase in tissue fluidity that similar to a solid-like-to-fluid-like transitional state. This transitional state allows cells to migrate under physical constraints without abolishing the cell cooperation required for collectiveness [99]. This enhanced cell metastatic potential is associated with poorer prognosis in cancer patients $[6,27]$. These tumor cell clusters preferentially display high level of the epithelial cytoskeletal protein keratin 14 (K14), desmosome and hemidesmosome adhesion complex genes but are depleted of major histocompatibility complex (MHC) class II genes [100].

Cancer cells within multicellular clusters can form nano alumina to construct their own internal microenvironment, from which they exchange and concentrate growth factors such as epigen to drive metastatic outgrowth [6]. Although E-cadherin has been widely demonstrated to inhibit cancer metastasis, E-cadherin is intriguingly required for the metastasis of invasive ductal carcinoma (IDC). This requirement is based on that E-cadherin enable cancer cells to form collective metastasis by reducing reactive oxygen species (ROS) and preventing cancer cells from apoptosis, which is especially critical during systemic dissemination and early seeding [39]. Clusters, usually containing as many as 20 cells, that are too large to pass through narrow vessels can reversibly reorganize into single-file chain-like geometries that reduce their hydrodynamic resistances, allowing them to successfully traverse $5 \sim 10 \mu \mathrm{m}$ constrictions, even in whole blood [101]. Correspondingly, PEP06 polypeptide 30, a cluster-dissociating agent, inhibits cancer metastasis by manipulating the EMT, the $\alpha_{\mathrm{v}}$ integrin/FAK/Src axis, and E-cadherin-based intercellular junctions $[102,103]$.

\section{Reprogramming metabolism}

Antioxidants $N$-acetylcysteine and vitamin E reduce ROS, free heme level, and stabilize the transcription factor BACH1, resulting in glycolysis-dependent metastasis of lung cancer cells [104]. This finding suggests that oxidative stress may have an inhibitory effect on metastasis at the initial stage. Metastatic melanoma cells but not primary melanoma cells are capable of engulfing and digesting live autologous melanoma-specific CD8 ${ }^{+}$ $\mathrm{T}$ cells to increase their survival, particularly under nutrient-stress conditions [105].

Some cancer stem cells (CSCs) do not display high levels of mesenchymal genes but express the high level of the fatty acid receptor CD36. These CSCs are critical for metastasis initiation and rely particularly on dietary lipids to promote metastasis [106]. Although the primary and lymph node metastases of melanoma cells display a similar level of cholesterol, metastatic cells in lymph nodes can probably produce or recruit more bile acids to activate vitamin D receptor/YAP, which promote metastatic cells adaptation to their new microenvironment [107].

Aerobic glycolysis (the Warburg effect) has been widely used as a marker of cancer $[9,108]$. FABP7 is increased in patients with breast cancer metastases in the brain. It inhibits fatty acid oxidative phosphorylation (OXPHOS) and enhances the formation of lipid droplets, which facilitates HER2 ${ }^{+}$breast cancer metastasis to the brain [109]. Moreover, DTCs may reprogram their metabolism to survive and colonize at metastatic sites. Micrometastatic triple-negative breast cancer (TNBC) cells in the lungs and lymph nodes upregulate mitochondrial OXPHOS, the pharmacological inhibition of which profoundly reduces lung metastasis [38]. CTCs display high expression of peroxisome proliferator-activated receptor-gamma $1 \alpha$ (PGC-1 $\alpha$ ), which is regulated by $\mathrm{Ca}^{2+}$ and is necessary for intravasation of cancer cells into the circulatory systems. PGC-1 $\alpha$ enhances mitochondrial biogenesis and respiration coupled with the remodeling of actin cytoskeleton signals. Silencing of PGC- $1 \alpha$ ultimately decreases the aggressive properties of cancer cells, such as metastatic lung colonization and nodule formation $[38,110]$. 


\section{Escape from immunosurveillance}

Leukocyte immunoglobulin-like receptor B4 (LILRB4) is exclusively expressed on monocytic cells. It inhibits $\mathrm{T}$ cell proliferation and $\mathrm{T}$ cell-mediated antitumor immunity meanwhile promoting acute myeloid leukemia (AML) cell migration and tumor infiltration [111]. Metastatic castration-resistant prostate cancer (mCRPC) cells induce an increase in the population of osteoclasts in bone marrow. Osteoclasts produce TGF $\beta$, which inhibits Th-1 polarization in the metastatic TME and is the cause of the poor response of metastatic cancer to immune checkpoint therapy [71]. Cancer cells that have metastasized to the liver can recruit macrophages and siphon-activated antigen-specific $\mathrm{T}$ cells. These macrophages display high expression of FasL, which diminishes $\mathrm{CD}^{+} \mathrm{T}$ cells through their direct contact, which induces FasL/Fasdependent apoptosis, resulting in systemic immunosuppression [7]. PHD restrains $\mathrm{CD}^{+} \mathrm{T}$ cell effector function, also leading to an immunosuppressive microenvironment that favors cancer cell colonization at the lung [64].

\section{Roles of calcium signaling in cancer metastasis}

$\mathrm{Ca}^{2+}$, a ubiquitous second messenger, is critical to cancer development, including metastasis and therapy resistance [17]. $\mathrm{Ca}^{2+}$ has been widely demonstrated to manipulate events critical to metastasis, including the EMT [112], invadosome formation, ECM degradation [113] and angiogenesis [114]. Serum $\mathrm{Ca}^{2+}$ level is positively associated with the risk of node metastasis in endometrial and breast cancer [115, 116], but low serum calcium level indicates poor distant metastasis-free survival of patients with nasopharyngeal carcinoma [117].

Cancer cells contacting with ECs induces oscillatory intracellular and intercellular $\mathrm{Ca}^{2+}$ waves in ECs that generated from the contact site. It coupled with ECs retraction that may be responsible for cancer metastasis [118]. Direct current electric field (dcEF)-mediated epidermal growth factor receptor (EGFR) polarization and $\mathrm{Ca}^{2+}$ influx promote cancer cell electrotaxis [119]. $\beta_{2}$-adrenoceptor initiates a cAMP-Ca ${ }^{2+}$ feedforward loop that enhances the invasion of breast cancer cells [120]. Metformin inhibits fibrosarcoma invasion and migration by reducing MMP9 activity in a $\mathrm{Ca}^{2+}$-dependent manner [121]. Several $\mathrm{Ca}^{2+}$ channel blockers have been demonstrated to inhibit cancer cell metastasis in diverse ways. Nifedipine and diltiazem reduce cancer cells adhesion to ECs and the metastasis rate by remodeling the tumor cell cytoskeleton, affecting cell mobility and inhibiting tumor cell-induced platelet aggregation [122].

\section{$\mathrm{Ca}^{2+}$-dependent proteins}

Numerous $\mathrm{Ca}^{2+}$-dependent proteins containing $\mathrm{Ca}^{2+}$-binding sites, such as calmodulin (CaM) [123, 124], $\mathrm{Ca}^{2+}$ / CaM-dependent kinase (CaMK) [125], calreticulin [126], $\mathrm{Ca}^{2+}$ sensor [127], $\mathrm{Ca}^{2+}$-sensing receptor (CaSR) [128], calpain [129], calcineurin [130], myosin light-chain kinase (MLCK) [131] and phospholipase S100 family proteins [132], have been widely proven to be vital to cancer metastasis. CaM, with four EF-hands, is one of the most important $\mathrm{Ca}^{2+}$ signal-decoding proteins. It can rapidly redistribute to subcellular compartments in response to various signals. Migration signals trigger a spatiotemporal redistribution of CaM to the leading edge of the migrating cell; for example, EGF induced CaM redistribution from the nucleus to the cytoplasm to activate invadopodia-associated proteins $[123,133]$. Calreticulin can inhibit ER stress to inhibit EMT, which promotes cancer cells liver metastasis [126]. CaSR located on the plasma membrane senses extracellular $\mathrm{Ca}^{2+}$. CaSR induces activation of AKT/ $\beta$-catenin, leading to cancer metastasis $[128,134]$. Calpain cleaves talin, resulting in more rapid adhesion disassembly rates [129]. Neuronal $\mathrm{Ca}^{2+}$ sensor 1 (NCS1) promotes the motility of cancer cells by localizing to the cell leading edge [135].

S100A4 reduces the expression of E-cadherin and $\beta$-catenin in cancer cells, while S100A4 ${ }^{+}$stromal cells enhance the stem cell-like phenotype of tumor cells $[136,137]$. S100A9 can be secreted by TAMs, which is increased in HCC-related TAMs and HCC cells. It enhances the stem cell-like and metastatic properties of HCC cells by activating NF- $\kappa B$ and recruiting more macrophages to infiltrate tumors $[138,139]$. $\mathrm{Ca}^{2+}$-activated potassium channels promote the proliferation and migration of endometrial and breast cancer cells, while they also mediate blood-brain tumor barrier opening to promote brain metastasis [140-142]. 
Limited by the scope of this brief review to cover all $\mathrm{Ca}^{2+}$-dependent proteins and protein-mediated $\mathrm{Ca}^{2+}$ currents, we mainly focus on the proteins critical for $\mathrm{Ca}^{2+}$ currents that have also been reported to be involved in cancer metastasis (Table 1).

Table 1. Representative studies about $\mathrm{Ca}^{2+}$ channels/pumps/uniporters in cancer metastasis

\begin{tabular}{|c|c|c|c|c|c|}
\hline \multicolumn{2}{|c|}{$\begin{array}{l}\text { Channels/Pumps/ } \\
\text { Uniporters }\end{array}$} & \multirow{2}{*}{$\begin{array}{l}\text { Alteration } \\
\uparrow\end{array}$} & \multirow{2}{*}{$\begin{array}{l}\text { Events/Mechanisms } \\
-\end{array}$} & \multirow{2}{*}{$\begin{array}{l}\text { Cancer type } \\
\text { CRC }\end{array}$} & \multirow{2}{*}{$\begin{array}{l}\text { Reference } \\
{[143]}\end{array}$} \\
\hline VGCC & Cav1.2 & & & & \\
\hline & Cav1.3 & $\uparrow$ & - & $\begin{array}{l}\text { Breast cancer, endometrial } \\
\text { carcinoma }\end{array}$ & {$[144,145]$} \\
\hline & Cav2.2 & $\uparrow$ & EMT & Breast cancer & [146] \\
\hline & Cav3.1/3.2 & - & - & $\begin{array}{l}\text { Glioblastoma, RAF }{ }^{\vee 600 E} \\
\text { melanoma }\end{array}$ & {$[147,148]$} \\
\hline \multirow[t]{7}{*}{ CRAC } & - & - & $\begin{array}{l}\text { Upregulation of MFAP5 derived } \\
\text { from CAFs increases SOCE in } \\
\text { cancer cells }\end{array}$ & Ovarian cancer & [149] \\
\hline & Orai1 & $\uparrow$ & $\begin{array}{l}\text { Focal adhesion turnover, } \\
\text { invadopodium formation, EMT and } \\
\text { extracellular matrix degradation }\end{array}$ & $\begin{array}{l}\text { Glioma, melanoma and } \\
\text { breast cancer }\end{array}$ & {$[13,150-153]$} \\
\hline & Orai2 & $\uparrow$ & Focal adhesion disassembly & GC & [154] \\
\hline & Orai3 & - & $\begin{array}{l}\text { Neuroendocrine-to-mesenchymal } \\
\text { transition }\end{array}$ & $\begin{array}{l}\text { Gastro-enteropancreatic } \\
\text { neuroendocrine tumor }\end{array}$ & [151] \\
\hline & STIM1 & $\uparrow$ & $\begin{array}{l}\text { Focal adhesion turnover and } \\
\text { invadopodium formation }\end{array}$ & $\begin{array}{l}\text { Melanoma, gastric and } \\
\text { breast cancer }\end{array}$ & {$[13,153,155]$} \\
\hline & STIM2 & $\uparrow$ & EMT & Breast cancer & [8] \\
\hline & MS4A12 & $\uparrow$ & - & Colon cancer & [156] \\
\hline \multirow[t]{19}{*}{ TRP channel } & TRPC1 & $\uparrow$ & EMT & Breast cancer & [157] \\
\hline & TRPC3 & $\uparrow$ & - & Melanoma & [158] \\
\hline & TRPC4 & - & - & Medulloblastoma & [159] \\
\hline & TRPC5 & $\uparrow$ & EMT & Colon cancer & [160] \\
\hline & TRPC6 & $\uparrow$ & EMT & Breast and gastric cancer & [161-163] \\
\hline & TRPM2 & - & EMT & Gastric cancer & [164] \\
\hline & TRPM3 & $\uparrow$ & EMT & Renal cell carcinoma & [165] \\
\hline & TRMP4 & $\uparrow$ & EMT & Prostate cancer & {$[166,167]$} \\
\hline & TRPM5 & - & MMP9 & Melanoma & [168] \\
\hline & TRPM7 & $\uparrow$ & EMT & $\begin{array}{l}\text { Nasopharyngeal carcinoma, } \\
\text { ovarian and breast cancer }\end{array}$ & [169-171] \\
\hline & TRPM8 & $\uparrow$ & EMT & Colon cancer & [172] \\
\hline & TRPML1 & - & Lysosomal exocytosis & Hepatocellular carcinoma & [173] \\
\hline & TRPP2 & $\uparrow$ & EMT & $\begin{array}{l}\text { Laryngeal squamous cell } \\
\text { carcinoma }\end{array}$ & [174] \\
\hline & TRPV1 & $\downarrow$ & Peritoneal dissemination & GC & [175] \\
\hline & TRPV2 & $\uparrow$ & - & $\begin{array}{l}\text { Prostate and esophageal } \\
\text { cancer }\end{array}$ & [176] \\
\hline & TRPV4 & $\uparrow$ & Matrix stiffness and EMT & $\begin{array}{l}\text { Endometrial and breast } \\
\text { cancer }\end{array}$ & {$[177,178]$} \\
\hline & & $\downarrow$ & Tumor vessel integrity & Prostate cancer & [179] \\
\hline & TRPV5 & $\downarrow$ & - & Renal cell carcinoma & [180] \\
\hline & TRPV6 & $\uparrow$ & - & Prostate cancer & [181] \\
\hline
\end{tabular}


Table 1. Representative studies about $\mathrm{Ca}^{2+}$ channels/pumps/uniporters in cancer metastasis (continued)

\begin{tabular}{|c|c|c|c|c|c|}
\hline \multicolumn{2}{|c|}{$\begin{array}{l}\text { Channels/Pumps/ } \\
\text { Uniporters }\end{array}$} & \multirow{2}{*}{$\begin{array}{l}\text { Alteration } \\
\downarrow\end{array}$} & \multirow{2}{*}{$\begin{array}{l}\text { Events/Mechanisms } \\
\text { EMT }\end{array}$} & \multirow{2}{*}{$\begin{array}{l}\text { Cancer type } \\
\text { GC }\end{array}$} & \multirow{2}{*}{$\begin{array}{l}\text { Reference } \\
{[182]}\end{array}$} \\
\hline ATP & PMCA4 & & & & \\
\hline dependent & SERCA & - & Focal adhesions & Glioblastoma & [183] \\
\hline & SERCA2 & $\uparrow$ & - & Colorectal cancer & [184] \\
\hline & SERCA3 & $\downarrow$ & - & $\begin{array}{l}\text { Colorectal adenoma- } \\
\text { adenocarcinoma }\end{array}$ & [185] \\
\hline & $\mathrm{P} 2 \times 7$ & $\uparrow$ & EMT and formation of filopodia & Melanoma and colon cancer & [186-188] \\
\hline & $\mathrm{P} 2 \mathrm{Y}$ & - & - & Colon cancer & [187] \\
\hline & P2Y2 & - & EMT & Prostate cancer & {$[189,190]$} \\
\hline & P2Y6 & - & Filopodia and focal adhesions & Lung cancer & [191] \\
\hline & $\mathrm{P} 2 \mathrm{Y} 12$ & - & $\begin{array}{l}\text { Positive regulation of Akt in } \\
\text { platelets }\end{array}$ & - & [192] \\
\hline \multirow{7}{*}{$\begin{array}{l}\text { MCU } \\
\text { complex }\end{array}$} & EMRE & $\downarrow$ & - & TNBC & [193] \\
\hline & MCU & $\uparrow$ & $\begin{array}{l}\text { ROS, MVD, tube formation and } \\
\text { sprouting capacity }\end{array}$ & $\begin{array}{l}\text { Hepatocellular carcinoma } \\
\text { and TNBC }\end{array}$ & [194-196] \\
\hline & MCUb & $\downarrow$ & ROS & TNBC & [196] \\
\hline & MICU1 & $\uparrow$ & ROS & TNBC & [193] \\
\hline & & $\downarrow$ & ROS & Hepatocellular carcinoma & [194] \\
\hline & MICU2 & $\uparrow$ & ROS & TNBC & [193] \\
\hline & MCUR1 & $\uparrow$ & EMT & $\mathrm{HCC}$ & [197] \\
\hline TPCs & Tpc2 & $\downarrow$ & EMT & Melanoma & [198] \\
\hline $\mathrm{IP}_{3} \mathrm{R}$ & $\mathrm{IP}_{3} \mathrm{R}-3$ & $\uparrow$ & - & Colorectal cancer & [199] \\
\hline RyR & RyR2 & $\downarrow$ & - & Thyroid carcinoma & [200] \\
\hline
\end{tabular}

$\uparrow$ : indicates increased; $\downarrow$ : indicates decreased; -: indicates not availab; VGCC: voltage-gated Ca ${ }^{2+}$ channel; MFAP5: microfibrillarassociated protein 5; SOCE: store-operated $\mathrm{Ca}^{2+}$ entry; STIM: stromal interaction molecule; TRP: transient receptor potential; TRPC: TRP canonical; TRPM: TRP melastatin; TRPML1: Mucolipin TRP channel 1; TRPP2: TRP polycystin 2; TRPV: TRP vanilloid; PMCA: plasma membrane $\mathrm{Ca}^{2+}$ ATPase; GC: gastric cancer; SERCA: (Sarco)-ER Ca ${ }^{2+}$ ATPase; MCU: mitochondrial calcium uniporter; EMRE: essential MCU regulator; MCUb: MCU dominant negative beta subunit; MICU: mitochondrial calcium uptake; MCUR1: MCU regulator 1; TPC: two-pore channel; IP $R$ : inositol 1,4,5-trisphosphate receptor; RyR: ryanodine receptor; MVD: microvessel density

\section{VGCCs}

VGCCs comprise five subtypes and ten members. Endostatin, a commercial agent targeting angiogenesis, reduces glioblastoma cells migration by directly inhibiting T-type VGCCs [147]. Cav1.3 expression is increased in breast cancer, atypical hyperplasia, and endometrial carcinoma tissues. It partially mediates estrogen-induced $\mathrm{Ca}^{2+}$ influx and endometrial carcinoma cells migration $[144,145] . \mathrm{Ca}^{2+}$ is increased at filopodia tips and correlated with filopodia stabilization. Filopodia stabilization leads to focal adhesion formation, which is critical to the migration of cells. L-type $\mathrm{Ca}^{2+}$ channel blockers, such as amlodipine, besylate, felodipine, manidipine, and cilnidipine, potently inhibit L-type $\mathrm{Ca}^{2+}$ channel/calpain-1-mediated filopodia formation, which efficiently reduces the cancer cells migration and invasion rates [145]. The Cav1.2 level is increased in CRCs. Nifedipine, another L-type $\mathrm{Ca}^{2+}$ channel blocker, inhibits CRC migration and PD-1 via Cav1.2/ $\mathrm{Ca}^{2+}$-mediated activation of nuclear factor of activated T cell 2 (NFAT2). The combination of nifedipine with an anti-PD-1 antibody significantly reduces cancer cell liver metastasis and the PD- $1^{+} \mathrm{CD} 8^{+} \mathrm{T}$ cells level among tumor-infiltrating lymphocytes [143].

\section{$\mathrm{Ca}^{2+}$ release-activated $\mathrm{Ca}^{2+}$ channels}

Orai proteins located on the cell membrane are the core components of $\mathrm{Ca}^{2+}$ release-activated $\mathrm{Ca}^{2+}$ channels (CRACs) that mediate SOCE. Upon ER $\mathrm{Ca}^{2+}$ depletion, STIM activates Orai to mediate $\mathrm{Ca}^{2+}$ influx. CRACs play critical roles not only in immune cells but also in cancer cells $[13,14,201]$. Chemoresistant ovarian cancer cells acquire enhanced migratory ability by increasing SOCE-mediated focal adhesion turnover [11]. ACE2 promotes metastasis of breast cancer by activating the PAK1/NF- $\mathrm{KB} /$ Snail1 axis via SOCE [202]. MFAP5 
secreted by CAFs activates FAK/cAMP response element-binding protein (CREB)/troponin C type 1 (TNNC1) via SOCE to enhance cancer metastasis [149].

CRAC-mediated $\mathrm{Ca}^{2+}$ regulates invadopodium formation and ECM degradation [155, 203]. Orai1-medated SOCE promotes phosphorylation of proline-rich tyrosine kinase 2 (Pyk2), which regulates focal adhesion turnover and the EMT of glioma cells [150]. Elevation of Orai2 is positively correlated with lymph node metastasis of gastric cancer (GC). Orai2 induces FAK-mediated mitogen-activated protein kinases(MAPK)/ extracellular signal-regulated kinase (ERK) activation and enhances focal adhesion disassembly at the rear edge of metastatic cancer cells [154]. The $\mathrm{hEag} 1 \mathrm{~K}^{+}$channels are essential for breast cancer cell migration because they promote Orai1-mediated $\mathrm{Ca}^{2+}$ current [204]. Inhibition of Orai or STIM decreases GTPase Rasand Rac-mediated formation of new focal complexes at cell protrusions and disassembly of focal adhesions. This action ultimately inhibits breast cancer metastasis to the lung [13]. Orai3 and STIM2 also promote gastroenteropancreatic neuroendocrine and breast cancer metastasis, respectively $[8,151]$.

\section{TRP channels}

The TRP channel superfamily comprises seven subtypes with approximately thirty members, most of which can mediate $\mathrm{Ca}^{2+}$ currents. TRP channels are activated by diverse stimuli, including intra- and extra-cellular messengers, temperature, $\mathrm{pH}$, chemical, mechanical and osmotic stress, ROS, and intracellular $\mathrm{Ca}^{2+}$ stores [17]. The expression of phospholipid phosphatase 4 (PLPP4) protein is increased, and it promotes cancer cells metastasis probably by activating TRPC channels-mediated $\mathrm{Ca}^{2+}$ influx [205]. TRPC1 inhibits the PI3K/AKT pathway and EMT, leading to reduced migration and invasion rates of cancer cells [157]. TRPC5 is elevated in colon cancer, which promotes cancer cell EMT and metastasis via the HIF- $1 \alpha /$ Twist axis. In addition to promoting the migration and invasiveness of renal cancer cells, the upregulated expression of TRPC6 is also required for translocation of Orai1 and Orai3 to the plasma membrane of metastatic breast cancer cells [161, 162]. Helicobacter pylori, a well-known major risk factor for GC, increases TRPC6 transcription and $\mathrm{Ca}^{2+}$ influx via the $\mathrm{Wnt} / \beta$-catenin pathway to enhance $\mathrm{GC}$ cells migration and invasion [163].

Cancer cells with high level of TRPM2 channels are more susceptible to neutrophil cytotoxicity. A reduction in TRPM2 expression leads to decreased tumor growth but increased DTC seeding potential in the premetastatic lung [206]. Upregulation of TRPM7 expression is correlated with the EMT and metastasis of ovarian cancer via the $\mathrm{Ca}^{2+}$-related PI3K/AKT axis [171]. The level of TRPV1 channels is reduced in human GC tissues. This reduction leads to decreased $\mathrm{Ca}^{2+} /$ calmodulin-dependent protein kinase kinase beta (CaMKK $\beta$ ) activity and contributes to GC peritoneal dissemination [175]. TRPV4 or TRPV6 is increased in endometrial, breast or prostate cancer, which promotes cancer cells metastasis [177, 178, 181]. Deletion of TRPV4 increases p-VEGFR2 ${ }^{\mathrm{Y} 1175}$ level and ECs migration [207]. However, deficiency of TRPV4 causes reduced vascular E-cadherin level and destabilizes tumor vessel integrity, leading to cancer cells lung metastasis [179].

\section{Adenine/uridine nucleotide-dependent proteins that mediate $\mathrm{Ca}^{2+}$ current}

Plasma membrane $\mathrm{Ca}^{2+}$ ATPase

Reduction in PMCA4 level increases zinc finger E-box binding homeobox 1 (ZEB1) expression and the nuclear accumulation of NFAT isoform c1 (NFATc1). PMCA4 ultimately lead to advanced tumor-nodemetastasis (TNM) stage and poor prognosis of GC patients. It also induces cancer cells transformation with elongated fibroblastoid morphology, reduced E-cadherin level and increased vimentin level, which can be inhibited by cyclosporine A [182].

\section{SERCA}

The miR-708 level is decreased in both lymph node and distal metastases, suggesting a cancer metastasissuppressive role of miR-708. Neuronatin is a membrane protein in the ER with the ability to inhibit SERCA. Reduction in miR-708 level increases the expression of neuronatin, which further induces the elevation of intracellular $\mathrm{Ca}^{2+}$ level to promote cell migration and metastasis formation by activating the ERK/FAK axis [183]. Upregulation of SERCA2 in CRCs is positively related to serosal invasion and lymph node metastasis [184]. In contrast, the SERCA3 level is negatively related to lymphatic invasion of colorectal adenoma-adenocarcinoma [185]. 


\section{Purinergic receptors}

P2*7 (*indicates X or Y) receptors are highly expressed on LoVo and SW480 CRCs. Activation of P2*7 by ATP promotes CRCs metastasis by STAT3-dependent EMT [187]. P2X7 promotes cancer invasiveness by sustaining the activity of cell division cycle 42 (Cdc42) and promoting the acquisition of a mesenchymal phenotype [186]. P2Y mediates prostate cancer invasion via ERK1/2 and p38 or EMT/invasion-related

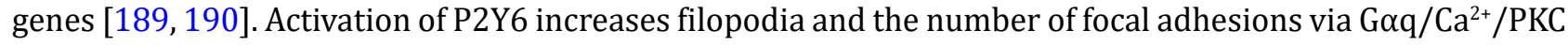
and $\mathrm{G \alpha}_{13} /$ Rho-associated protein kinase-dependent pathways to promote lung cancer cell migration [191]. Depletion of apoptosis signal-regulating kinase 1 (ASK1) reduces the phosphorylation of P2Y12 in platelets, which leads to defects in platelet aggregation and a reduction in tumor metastasis [192].

\section{Mitochondrial calcium uniporter}

Mitochondria, major intracellular $\mathrm{Ca}^{2+}$ stores, are primary sources of ROS, which promote tumor metastasis. MCU located on the inner mitochondrial membrane, is a $\mathrm{Ca}^{2+}$-selective channel and critical for major $\mathrm{Ca}^{2+}$ influx into mitochondria [208]. MCU-mediated ATP production regulates profibrotic macrophage polarization [209]. cl-CD95L enhances the metastatic dissemination of TNBC cells by enhancing MCUmediated $\mathrm{Ca}^{2+}$ current [210]. However, reduction in histidine triad nucleotide-binding 2 (HINT2) enhances pancreatic cancer lymph node metastasis, probably by increasing MICU1/2 and decreasing EMRE levels to inhibit MCU activity [193, 211].

MCU is significantly associated with cancer aggressiveness and is increased in diverse cancers, including TNBC, HCC, and GC [88, 194-196]. Elevation of MCU level enhances metastatic colonization and MVD in breast cancer. MCU also inhibits the selective sorting of miR-4488 to extracellular vesicles by manipulating $\mathrm{Ca}^{2+}$-dependent RNA-binding proteins (RBPs). This process leads to relief of C-X3-C motif chemokine ligand 1 (CX3CL1) repression to enhance tube formation capacity and sprouting capacity [195]. MCUb expression is decreased while that of MCU is increased in invasive TNBC and lymph node metastasis. Silencing MCU increases SOCE and the NADPH/NADH ratio while decreases ROS and HIF-1 $\alpha$ levels [196]. MICU1 is decreased in metastatic HCC tissues, and MCU-mediated mitochondrial $\mathrm{Ca}^{2+}$ influx induces ROS/ c-Jun N-terminal kinase (JNK) activation. This chain of events ultimately facilitates HCC intrahepatic and lung metastasis [194]. MCUR1 is significantly upregulated in metastatic HCC cells, which promote EMT and metastasis via the mitochondrial $\mathrm{Ca}^{2+}$-dependent ROS/Nrf2/Notch pathway [197].

TPC

TPC family proteins are nicotinic acid adenine dinucleotide phosphate (NAADP)-gated $\mathrm{Ca}^{2+}$ release channels located on endosomes, lysosomes, and melanosomes. Reduction in TPC2 expression activates the YAP/TAZ axis to inhibit the expression levels of ORAI1 and PKC- $\beta$ II, which is found in the metastatic tumors but not in the primary melanoma cells in patients [198].

\section{$I_{3} R$ and RyR}

The EGF-induced EMT is coupled with specific alterations in the mRNA level of ER-related $\mathrm{Ca}^{2+}$ channels/pumps, including SERCAs, $\mathrm{IP}_{3} \mathrm{R}$, and RyR [212]. Trifluoperazine, an antipsychotic drug, can reduce glioblastoma invasion by binding with CaM to activate $\mathrm{IP}_{3} \mathrm{R}$-mediated $\mathrm{Ca}^{2+}$ release from the ER [213]. Furthermore, $I_{3} \mathrm{R}-3$ is increased in colon cancer, while RyR2 is decreased in thyroid carcinoma tissues, both of which are related to aggressiveness $[199,200]$.

\section{Conclusions}

Metastasis is still a great challenge for improving cancer therapy, in which $\mathrm{Ca}^{2+}$-manipulated signals have been proven to be critical. Currently, although great progress has been made, the mechanisms underlying the metastatic cascade and functions of $\mathrm{Ca}^{2+}$ have not yet been fully elucidated. Most previous studies have focused mainly on $\mathrm{Ca}^{2+}$-dependent proteins or $\mathrm{Ca}^{2+}$ channels/pumps/uniporters in cancer cells, while only a few studies have investigated their functions in cancer stoma cells and the metastatic niche. There are still limited available drugs targeting $\mathrm{Ca}^{2+}$-mediated signals in the clinic or undergoing clinical trials for cancer 
metastasis therapy. Therefore, the development of drugs specifically targeting proteins that decoding calcium oscillation signals or mediating $\mathrm{Ca}^{2+}$ currents is highly desirable.

\section{Abbreviations}

ALDOB: aldolase B

AMP: adenosine monophosphate

AMPK: AMP-activated protein kinase

$\mathrm{Ca}^{2+}:$ calcium ions

CAFs: cancer-associated fibroblasts

CaM: calmodulin

CaSR: $\mathrm{Ca}^{2+}$ sensing receptor

CCL: C-C motif ligand

CIL: contact inhibition of locomotion

CRACs: $\mathrm{Ca}^{2+}$ release-activated $\mathrm{Ca}^{2+}$ channels

CRCs: colon cancer cells

CTCs: circulating tumor cells

CXC: C-X-C motif

CXCL: CXC chemokine ligand

DTCs: disseminated tumor cells

ECM: extracellular matrix

ECs: endothelial cells

EGF: epidermal growth factor

EMRE: essential MCU regulator

EMT: epithelial-to-mesenchymal transition

EphA2: Ephrin type-A receptor 2

ER: endoplasmic reticulum

ERK: extracellular signal-regulated kinase

FAK: focal adhesion kinase

GC: gastric cancer

gMDSCs: granulocytic MDSCs

HCC: hepatocellular carcinoma

HIF-1 $\alpha$ : hypoxia-inducible factor-1alpha

IL-6: interleukin-6

$\mathrm{IP}_{3} \mathrm{R}$ : inositol 1,4,5-trisphosphate receptor

LECs: lymphatic ECs

MCT1: monocarboxylate transporter 1

MCU: mitochondrial calcium uniporter

MDSCs: myeloid derived suppressor cells

MET: mesenchymal-epithelial transition

MICU: mitochondrial calcium uptake

MMPs: matrix metalloproteinases

NF-кB: nuclear factor-kappa B 
NK: natural killer

PGC-1 $\alpha$ : peroxisome proliferator-activated receptor-gamma coactivator $1 \alpha$

PHD: prolyl-hydroxylase

PMCA: plasma membrane $\mathrm{Ca}^{2+}$ ATPase

PTEN: phosphatase and tensin homolog

ROS: reactive oxygen species

RPs: ribosomal proteins

RyR: ryanodine receptor

SERCA: (sarco)-endoplasmic reticulum $\mathrm{Ca}^{2+}$ ATPase

SOCE: store-operated $\mathrm{Ca}^{2+}$ entry

STAT3: signal transducer and activator of transcription 3

TAMs: tumor-associated macrophages

TGF $\beta$ : transforming growth factor $\beta$

TME: tumor microenvironment

TNBC: triple negative breast cancer

TPCs: two-pore channels

TRP: transient receptor potential

TRPC: TRP canonica

TRPM: TRP melastatin

TRPV: TRPV vanilloid

VGCCs: voltage-gated $\mathrm{Ca}^{2+}$ channels

\section{Declarations}

Author contributions

CCC, ZYX and WXW contributed to the conception and design of the review. CCC, ZYX, LG, ZSH and ZJH collected the related reports and drafted the manuscript. All authors contributed to manuscript revision, read and approved the submitted version.

\section{Conflicts of interest}

The authors declare that they have no conflicts of interest.

\section{Ethical approval}

Not applicable.

\section{Consent to participate}

Not applicable.

\section{Consent to publication}

Not applicable.

Availability of data and materials

Not applicable.

\section{Funding}

This work was sponsored by the National Natural Science Foundation of China (No. 81902442), Natural Science Foundation of Henan for Excellent Young Scholars (No. 202300410309), Key Scientific Research Projects of Henan for College (No. 20A320010) and Start-up Funds of Xinxiang Medical University (No. 
505284). The funders had no role in study design, data collection and analysis, decision to publish, or preparation of the manuscript.

\section{Copyright}

(C) The Author(s) 2021.

\section{References}

1. Guo S, Chen J, Chen F, Zeng Q, Liu WL, Zhang G. Exosomes derived from Fusobacterium nucleatuminfected colorectal cancer cells facilitate tumour metastasis by selectively carrying miR-1246/92b3p/27a-3p and CXCL16. Gut. Forthcoming 2021.

2. Gaggioli C, Hooper S, Hidalgo-Carcedo C, Grosse R, Marshall JF, Harrington K, et al. Fibroblast-led collective invasion of carcinoma cells with differing roles for RhoGTPases in leading and following cells. Nat Cell Biol. 2007;9:1392-400.

3. Dai W, Guo X, Cao Y, Mondo JA, Campanale JP, Montell BJ, et al. Tissue topography steers migrating Drosophila border cells. Science. 2020;370:987-90.

4. Nieman KM, Kenny HA, Penicka CV, Ladanyi A, Buell-Gutbrod R, Zillhardt MR, et al. Adipocytes promote ovarian cancer metastasis and provide energy for rapid tumor growth. Nat Med. 2011;17:1498-503.

5. Zhang J, Wang S, Jiang B, Huang L, Ji Z, Li X, et al. c-Src phosphorylation and activation of hexokinase promotes tumorigenesis and metastasis. Nat Commun. 2017;8:13732.

6. Wrenn ED, Yamamoto A, Moore BM, Huang Y, McBirney M, Thomas AJ, et al. Regulation of collective metastasis by nanolumenal signaling. Cell. 2020;183:395-410.e19.

7. Yu J, Green MD, Li S, Sun Y, Journey SN, Choi JE, et al. Liver metastasis restrains immunotherapy efficacy via macrophage-mediated T cell elimination. Nat Med. 2021;27:152-64.

8. Miao Y, Shen Q, Zhang S, Huang H, Meng X, Zheng X, et al. Calcium-sensing stromal interaction molecule 2 upregulates nuclear factor of activated T cells 1 and transforming growth factor- $\beta$ signaling to promote breast cancer metastasis. Breast Cancer Res. 2019;21:99.

9. Hanahan D, Weinberg RA. Hallmarks of cancer: the next generation. Cell. 2011;144:646-74.

10. Hosseini H, Obradović MMS, Hoffmann M, Harper KL, Sosa MS, Werner-Klein M, et al. Early dissemination seeds metastasis in breast cancer. Nature. 2016;540:552-8.

11. Huang HK, Lin YH, Chang HA, Lai YS, Chen YC, Huang SC, et al. Chemoresistant ovarian cancer enhances its migration abilities by increasing store-operated $\mathrm{Ca}^{2+}$ entry-mediated turnover of focal adhesions. J Biomed Sci. 2020;27:36.

12. Hu JL, Wang W, Lan XL, Zeng ZC, Liang YS, Yan YR, et al. CAFs secreted exosomes promote metastasis and chemotherapy resistance by enhancing cell stemness and epithelial-mesenchymal transition in colorectal cancer. Mol Cancer. 2019;18:91.

13. Yang S, Zhang JJ, Huang XY. Orai1 and STIM1 are critical for breast tumor cell migration and metastasis. Cancer Cell. 2009;15:124-34.

14. Feske S, Gwack Y, Prakriya M, Srikanth S, Puppel SH, Tanasa B, et al. A mutation in Orai1 causes immune deficiency by abrogating CRAC channel function. Nature. 2006;441:179-85.

15. Choi S, Cui C, Luo Y, Kim SH, Ko JK, Huo X, et al. Selective inhibitory effects of zinc on cell proliferation in esophageal squamous cell carcinoma through Orai1. FASEB J. 2018;32:404-16.

16. Alessandro R, Masiero L, Liotta LA, Kohn EC. The role of calcium in the regulation of invasion and angiogenesis. In Vivo. 1996;10:153-60.

17. Cui C, Merritt R, Fu L, Pan Z. Targeting calcium signaling in cancer therapy. Acta Pharmaceutica Sinica B. 2017;7:3-17.

18. Webb DJ, Parsons JT, Horwitz AF. Adhesion assembly, disassembly and turnover in migrating cells--over and over and over again. Nat Cell Biol. 2002;4:E97-100. 
19. Fidler IJ, Poste G. The "seed and soil" hypothesis revisited. Lancet Oncol. 2008;9:808.

20. Fife CM, McCarroll JA, Kavallaris M. Movers and shakers: cell cytoskeleton in cancer metastasis. Br J Pharmacol. 2014;171:5507-23.

21. Li Y, Zhang Z, Zhou X, Li L, Liu Q, Wang Z, et al. The oncoprotein HBXIP enhances migration of breast cancer cells through increasing filopodia formation involving MEKK2/ERK1/2/Capn4 signaling. Cancer Lett. 2014;355:288-96.

22. Tang Y, He Y, Zhang P, Wang J, Fan C, Yang L, et al. LncRNAs regulate the cytoskeleton and related Rho/ ROCK signaling in cancer metastasis. Mol Cancer. 2018;17:77.

23. Harada $\mathrm{H}$, Inoue M, Itasaka S, Hirota K, Morinibu A, Shinomiya K, et al. Cancer cells that survive radiation therapy acquire HIF-1 activity and translocate towards tumour blood vessels. Nat Commun. 2012;3:783.

24. Sabeh F, Shimizu-Hirota R, Weiss SJ. Protease-dependent versus -independent cancer cell invasion programs: three-dimensional amoeboid movement revisited. J Cell Biol. 2009;185:11-9.

25. Orgaz JL, Pandya P, Dalmeida R, Karagiannis P, Sanchez-Laorden B, Viros A, et al. Diverse matrix metalloproteinase functions regulate cancer amoeboid migration. Nat Commun. 2014;5:4255.

26. Friedl P, Wolf K. Tube travel: the role of proteases in individual and collective cancer cell invasion. Cancer Res. 2008;68:7247-9.

27. Aceto N, Bardia A, Miyamoto DT, Donaldson MC, Wittner BS, Spencer JA, et al. Circulating tumor cell clusters are oligoclonal precursors of breast cancer metastasis. Cell. 2014;158:1110-22.

28. Denais CM, Gilbert RM, Isermann P, McGregor AL, te Lindert M, Weigelin B, et al. Nuclear envelope rupture and repair during cancer cell migration. Science. 2016;352:353-8.

29. Denny SK, Yang D, Chuang CH, Brady JJ, Lim JS, Grüner BM, et al. Nfib promotes metastasis through a widespread increase in chromatin accessibility. Cell. 2016;166:328-42.

30. Goodarzi H, Nguyen HCB, Zhang S, Dill BD, Molina H, Tavazoie SF. Modulated expression of specific tRNAs drives gene expression and cancer progression. Cell. 2016;165:1416-27.

31. Ebright RY, Lee S, Wittner BS, Niederhoffer KL, Nicholson BT, Bardia A, et al. Deregulation of ribosomal protein expression and translation promotes breast cancer metastasis. Science. 2020;367:1468-73.

32. Harper KL, Sosa MS, Entenberg D, Hosseini H, Cheung JF, Nobre R, et al. Mechanism of early dissemination and metastasis in $\mathrm{Her}^{2+}$ mammary cancer. Nature. 2016;540:588-92.

33. Rhim AD, Mirek ET, Aiello NM, Maitra A, Bailey JM, McAllister F, et al. EMT and dissemination precede pancreatic tumor formation. Cell. 2012;148:349-61.

34. Lin B, Yin T, Wu YI, Inoue T, Levchenko A. Interplay between chemotaxis and contact inhibition of locomotion determines exploratory cell migration. Nat Commun. 2015;6:6619.

35. Ouzounova M, Lee E, Piranlioglu R, El Andaloussi A, Kolhe R, Demirci MF, et al. Monocytic and granulocytic myeloid derived suppressor cells differentially regulate spatiotemporal tumour plasticity during metastatic cascade. Nat Commun. 2017;8:14979.

36. Sugiyama N, Gucciardo E, Tatti O, Varjosalo M, Hyytiainen M, Gstaiger M, et al. EphA2 cleavage by MT1MMP triggers single cancer cell invasion via homotypic cell repulsion. J Cell Biol. 2013;201:467-84.

37. Tasdogan A, Faubert B, Ramesh V, Ubellacker JM, Shen B, Solmonson A, et al. Metabolic heterogeneity confers differences in melanoma metastatic potential. Nature. 2020;577:115-20.

38. LeBleu VS, O'Connell JT, Gonzalez Herrera KN, Wikman H, Pantel K, Haigis MC, et al. PGC-1 $\alpha$ mediates mitochondrial biogenesis and oxidative phosphorylation in cancer cells to promote metastasis. Nat Cell Biol. 2014;16:992-1003, 1-15.

39. Padmanaban V, Krol I, Suhail Y, Szczerba BM, Aceto N, Bader JS, et al. E-cadherin is required for metastasis in multiple models of breast cancer. Nature. 2019;573:439-44.

40. Piskounova E, Agathocleous M, Murphy MM, Hu Z, Huddlestun SE, Zhao Z, et al. Oxidative stress inhibits distant metastasis by human melanoma cells. Nature. 2015;527:186-91. 
41. Hanna RN, Cekic C, Sag D, Tacke R, Thomas GD, Nowyhed H, et al. Patrolling monocytes control tumor metastasis to the lung. Science. 2015;350:985-90.

42. Ubellacker JM, Tasdogan A, Ramesh V, Shen B, Mitchell EC, Martin-Sandoval MS, et al. Lymph protects metastasizing melanoma cells from ferroptosis. Nature. 2020;585:113-8.

43. Zhao Z, Wu MS, Zou C, Tang Q, Lu J, Liu D, et al. Downregulation of MCT1 inhibits tumor growth, metastasis and enhances chemotherapeutic efficacy in osteosarcoma through regulation of the NF- $\kappa \mathrm{B}$ pathway. Cancer Lett. 2014;342:150-8.

44. Barrow-McGee R, Kishi N, Joffre C, Ménard L, Hervieu A, Bakhouche BA, et al. Beta 1-integrin-c-Met cooperation reveals an inside-in survival signalling on autophagy-related endomembranes. Nat Commun. 2016;7:11942.

45. Wolf MJ, Hoos A, Bauer J, Boettcher S, Knust M, Weber A, et al. Endothelial CCR2 signaling induced by colon carcinoma cells enables extravasation via the JAK2-Stat5 and p38MAPK pathway. Cancer Cell. 2012;22:91-105.

46. Olmeda D, Cerezo-Wallis D, Riveiro-Falkenbach E, Pennacchi PC, Contreras-Alcalde M, Ibarz N, et al. Whole-body imaging of lymphovascular niches identifies pre-metastatic roles of midkine. Nature. 2017;546:676-80.

47. Png KJ, Halberg N, Yoshida M, Tavazoie SF. A microRNA regulon that mediates endothelial recruitment and metastasis by cancer cells. Nature. 2011;481:190-4.

48. Karnezis T, Shayan R, Caesar C, Roufail S, Harris NC, Ardipradja K, et al. VEGF-D promotes tumor metastasis by regulating prostaglandins produced by the collecting lymphatic endothelium. Cancer Cell. 2012;21:181-95.

49. Lee E, Fertig EJ, Jin K, Sukumar S, Pandey NB, Popel AS. Breast cancer cells condition lymphatic endothelial cells within pre-metastatic niches to promote metastasis. Nat Commun. 2014;5:4715.

50. Chen XJ, Wei WF, Wang ZC, Wang N, Guo CH, Zhou CF, et al. A novel lymphatic pattern promotes metastasis of cervical cancer in a hypoxic tumour-associated macrophage-dependent manner. Forthcoming 2021.

51. Labelle M, Begum S, Hynes RO. Direct signaling between platelets and cancer cells induces an epithelialmesenchymal-like transition and promotes metastasis. Cancer Cell. 2011;20:576-90.

52. Papa AL, Jiang A, Korin N, Chen MB, Langan ET, Waterhouse A, et al. Platelet decoys inhibit thrombosis and prevent metastatic tumor formation in preclinical models. Sci Transl Med. 2019;11:eaau5898.

53. Zheng X, Liu J, Li X, Tian R, Shang K, Dong X, et al. Angiogenesis is promoted by exosomal DPP4 derived from 5-fluorouracil-resistant colon cancer cells. Cancer Lett. 2021;497:190-201.

54. Schwartz H, Blacher E, Amer M, Livneh N, Abramovitz L, Klein A, et al. Incipient melanoma brain metastases instigate astrogliosis and neuroinflammation. Cancer Res. 2016;76:4359-71.

55. Strilic B, Yang L, Albarrán-Juárez J, Wachsmuth L, Han K, Müller UC, et al. Tumour-cell-induced endothelial cell necroptosis via death receptor 6 promotes metastasis. Nature. 2016;536:215-8.

56. Wieland E, Rodriguez-Vita J, Liebler SS, Mogler C, Moll I, Herberich SE, et al. Endothelial Notch1 activity facilitates metastasis. Cancer Cell. 2017;31:355-67.

57. Connor Y, Tekleab S, Nandakumar S, Walls C, Tekleab Y, Husain A, et al. Physical nanoscale conduitmediated communication between tumour cells and the endothelium modulates endothelial phenotype. Nat Commun. 2015;6:8671.

58. Wagenblast E, Soto M, Gutiérrez-Ángel S, Hartl CA, Gable AL, Maceli AR, et al. A model of breast cancer heterogeneity reveals vascular mimicry as a driver of metastasis. Nature. 2015;520:358-62.

59. Lugassy C, Kleinman HK, Vermeulen PB, Barnhill RL. Angiotropism, pericytic mimicry and extravascular migratory metastasis: an embryogenesis-derived program of tumor spread. Angiogenesis. 2020;23: $27-41$. 
60. Aguirre-Ghiso JA. Models, mechanisms and clinical evidence for cancer dormancy. Nat Rev Cancer. 2007;7:834-46.

61. Bartosh TJ, Ullah M, Zeitouni S, Beaver J, Prockop DJ. Cancer cells enter dormancy after cannibalizing mesenchymal stem/stromal cells (MSCs). Proc Natl Acad Sci U S A. 2016;113:E6447-56.

62. Guldner IH, Wang Q Yang L, Golomb SM, Zhao Z, Lopez JA, et al. CNS-native myeloid cells drive immune suppression in the brain metastatic niche through cxcl10. Cell. 2020;183:1234-48.e25.

63. Wu Z, Wei D, Gao W, Xu Y, Hu Z, Ma Z, et al. TPO-induced metabolic reprogramming drives liver metastasis of colorectal cancer CD110+ tumor-initiating cells. Cell Stem Cell. 2015;17:47-59.

64. Clever D, Roychoudhuri R, Constantinides MG, Askenase MH, Sukumar M, Klebanoff CA, et al. Oxygen sensing by T cells establishes an immunologically tolerant metastatic niche. Cell. 2016;166:1117-31.e14.

65. Howe EN, Burnette MD, Justice ME, Schnepp PM, Hedrick V, Clancy JW, et al. Rab11b-mediated integrin recycling promotes brain metastatic adaptation and outgrowth. Nat Commun. 2020;11:3017.

66. Ramel D, Wang X, Laflamme C, Montell DJ, Emery G. Rab11 regulates cell-cell communication during collective cell movements. Nat Cell Biol. 2013;15:317-24.

67. Loo JM, Scherl A, Nguyen A, Man FY, Weinberg E, Zeng Z, et al. Extracellular metabolic energetics can promote cancer progression. Cell. 2015;160:393-406.

68. Zhang L, Zhang S, Yao J, Lowery FJ, Zhang Q, Huang WC, et al. Microenvironment-induced PTEN loss by exosomal microRNA primes brain metastasis outgrowth. Nature. 2015;527:100-4.

69. Hugo H, Ackland ML, Blick T, Lawrence MG, Clements JA, Williams ED, et al. Epithelial--mesenchymal and mesenchymal--epithelial transitions in carcinoma progression. J Cell Physiol. 2007;213:374-83.

70. Del Pozo Martin Y, Park D, Ramachandran A, Ombrato L, Calvo F, Chakravarty P, et al. Mesenchymal cancer cell-stroma crosstalk promotes niche aactivation, epithelial reversion, and metastatic colonization. Cell Rep. 2015;13:2456-69.

71. Jiao S, Subudhi SK, Aparicio A, Ge Z, Guan B, Miura Y, et al. Differences in tumor microenvironment dictate T helper lineage polarization and response to immune checkpoint therapy. Cell. 2019;179:1177-90 e13.

72. Houg DS, Bijlsma MF. The hepatic pre-metastatic niche in pancreatic ductal adenocarcinoma. Molecular Cancer. 2018;17:95.

73. Liu Y, Gu Y, Han Y, Zhang Q Jiang Z, Zhang X, et al. Tumor exosomal RNAs promote lung pre-metastatic niche formation by activating alveolar epithelial TLR3 to recruit neutrophils. Cancer Cell. 2016;30:243-56.

74. Barkan D, Green JE, Chambers AF. Extracellular matrix: a gatekeeper in the transition from dormancy to metastatic growth. Eur J Cancer. 2010;46:1181-8.

75. Cox TR, Rumney RMH, Schoof EM, Perryman L, Høye AM, Agrawal A, et al. The hypoxic cancer secretome induces pre-metastatic bone lesions through lysyl oxidase. Nature. 2015;522:106-10.

76. Hoshino A, Costa-Silva B, Shen TL, Rodrigues G, Hashimoto A, Tesic Mark M, et al. Tumour exosome integrins determine organotropic metastasis. Nature. 2015;527:329-35.

77. Headley MB, Bins A, Nip A, Roberts EW, Looney MR, Gerard A, et al. Visualization of immediate immune responses to pioneer metastatic cells in the lung. Nature. 2016;531:513-7.

78. Cai Z, Li CF, Han F, Liu C, Zhang A, Hsu CC, et al. Phosphorylation of PDHA by AMPK drives TCA cycle to promote cancer metastasis. Mol Cell. 2020;80:263-78.e7.

79. Bu P, Chen KY, Xiang K, Johnson C, Crown SB, Rakhilin N, et al. Aldolase B-mediated fructose metabolism drives metabolic reprogramming of colon cancer liver metastasis. Cell Metab. 2018;27:1249-62.e4.

80. Kim J, Kang J, Kang YL, Woo J, Kim Y, Huh J, et al. Ketohexokinase-A acts as a nuclear protein kinase that mediates fructose-induced metastasis in breast cancer. Nat commun. 2020;11:5436.

81. Cui C, Yang J, Li X, Liu D, Fu L, Wang X. Functions and mechanisms of circular RNAs in cancer radiotherapy and chemotherapy resistance. Mol Cancer. 2020;19:58-73. 
82. Hao J. The role of acidic microenvironment in the tumor aggressive phenotypes and the treatment. Tradit Med Res. 2020;5:4-6.

83. Qian BZ, Pollard JW. Macrophage diversity enhances tumor progression and metastasis. Cell. 2010;141:39-51.

84. Nejman D, Livyatan I, Fuks G, Gavert N, Zwang Y, Geller LT, et al. The human tumor microbiome is composed of tumor type-specific intracellular bacteria. Science. 2020;368:973-80.

85. Puram SV, Tirosh I, Parikh AS, Patel AP, Yizhak K, Gillespie S, et al. Single-cell transcriptomic analysis of primary and metastatic tumor ecosystems in head and neck cancer. Cell. 2017;171:1611-24.e24.

86. Astin JW, Batson J, Kadir S, Charlet J, Persad RA, Gillatt D, et al. Competition amongst Eph receptors regulates contact inhibition of locomotion and invasiveness in prostate cancer cells. Nat Cell Biol. 2010;12:1194-204.

87. Ershaid N, Sharon Y, Doron H, Raz Y, Shani O, Cohen N, et al. NLRP3 inflammasome in fibroblasts links tissue damage with inflammation in breast cancer progression and metastasis. Nat Commun. 2019;10:4375.

88. Wang X, Song X, Cheng G, Zhang J, Dong L, Bai J, et al. The regulatory mechanism and biological significance of mitochondrial calcium uniporter in the migration, invasion, angiogenesis and growth of gastric cancer. Onco Targets Ther. 2020;13:11781-94.

89. Shang S, Ji X, Zhang L, Chen J, Li C, Shi R, et al. Macrophage ABHD5 suppresses NFkB-dependent matrix metalloproteinase expression and cancer metastasis. Cancer Res. 2019;79:5513-26.

90. Srivastava K, Hu J, Korn C, Savant S, Teichert M, Kapel SS, et al. Postsurgical adjuvant tumor therapy by combining anti-angiopoietin-2 and metronomic chemotherapy limits metastatic growth. Cancer Cell. 2014;26:880-95.

91. Fan QM, Jing YY, Yu GF, Kou XR, Ye F, Gao L, et al. Tumor-associated macrophages promote cancer stem cell-like properties via transforming growth factor-beta1-induced epithelial-mesenchymal transition in hepatocellular carcinoma. Cancer Lett. 2014;352:160-8.

92. Yang Y, Andersson P, Hosaka K, Zhang Y, Cao R, Iwamoto H, et al. The PDGF-BB-SOX7 axis-modulated IL-33 in pericytes and stromal cells promotes metastasis through tumour-associated macrophages. Nat Commun. 2016;7:11385.

93. Karnoub AE, Dash AB, Vo AP, Sullivan A, Brooks MW, Bell GW, et al. Mesenchymal stem cells within tumour stroma promote breast cancer metastasis. Nature. 2007;449:557-63.

94. Chen YC, Gonzalez ME, Burman B, Zhao X, Anwar T, Tran M, et al. Mesenchymal stem/stromal cell engulfment reveals metastatic advantage in breast cancer. Cell Rep. 2019;27:3916-26.e5.

95. Jung Y, Kim JK, Shiozawa Y, Wang J, Mishra A, Joseph J, et al. Recruitment of mesenchymal stem cells into prostate tumours promotes metastasis. Nat Commun. 2013;4:1795.

96. Gast CE, Silk AD, Zarour L, Riegler L, Burkhart JG, Gustafson KT, et al. Cell fusion potentiates tumor heterogeneity and reveals circulating hybrid cells that correlate with stage and survival. Sci Adv. 2018;4:eaat7828.

97. Zomer A, Maynard C, Verweij FJ, Kamermans A, Schäfer R, Beerling E, et al. In vivo imaging reveals extracellular vesicle-mediated phenocopying of metastatic behavior. Cell. 2015;161:1046-57.

98. Neelakantan D, Zhou H, Oliphant MUJ, Zhang X, Simon LM, Henke DM, et al. EMT cells increase breast cancer metastasis via paracrine GLI activation in neighbouring tumour cells. Nat Commun. 2017;8:15773.

99. Kuriyama S, Theveneau E, Benedetto A, Parsons M, Tanaka M, Charras G, et al. In vivo collective cell migration requires an LPAR2-dependent increase in tissue fluidity. J Cell Biol. 2014;206:113-27.

100. Cheung KJ, Padmanaban V, Silvestri V, Schipper K, Cohen JD, Fairchild AN, et al. Polyclonal breast cancer metastases arise from collective dissemination of keratin 14-expressing tumor cell clusters. Proc Natl Acad Sci U S A. 2016;113:E854-63. 
101. Au SH, Storey BD, Moore JC, Tang Q, Chen YL, Javaid S, et al. Clusters of circulating tumor cells traverse capillary-sized vessels. Proc Natl Acad Sci U S A. 2016;113:4947-52.

102. Tuguzbaeva G, Yue E, Chen X, He L, Li X, Ju J, et al. PEP06 polypeptide 30 is a novel cluster-dissociating agent inhibiting $\alpha v$ integrin/FAK/Src signaling in oral squamous cell carcinoma cells. Acta Pharm Sin B. 2019;9:1163-73.

103. Yu S, Li L, Tian W, Nie D, Mu W, Qiu F, et al. PEP06 polypeptide 30 exerts antitumour effect in colorectal carcinoma via inhibiting epithelial-mesenchymal transition. Br J Pharmacol. 2018;175:3111-30.

104. Wiel C, Le Gal K, Ibrahim MX, Jahangir CA, Kashif M, Yao H, et al. BACH1 stabilization by antioxidants stimulates lung cancer metastasis. Cell. 2019;178:330-45.e22.

105. Lugini L, Matarrese P, Tinari A, Lozupone F, Federici C, Iessi E, et al. Cannibalism of live lymphocytes by human metastatic but not primary melanoma cells. Cancer Res. 2006;66:3629-38.

106. Pascual G, Avgustinova A, Mejetta S, Martín M, Castellanos A, Attolini CS, et al. Targeting metastasisinitiating cells through the fatty acid receptor CD36. Nature. 2017;541:41-5.

107. Lee CK, Jeong SH, Jang C, Bae H, Kim YH, Park I, et al. Tumor metastasis to lymph nodes requires YAPdependent metabolic adaptation. Science. 2019;363:644-9.

108. Bhattacharya B, Mohd Omar MF, Soong R. The Warburg effect and drug resistance. Br J Pharmacol. 2016;173:970-9.

109. Cordero A, Kanojia D, Miska J, Panek WK, Xiao A, Han Y, et al. FABP7 is a key metabolic regulator in HER ${ }^{2+}$ breast cancer brain metastasis. Oncogene. 2019;38:6445-60.

110. Gu L, Larson Casey JL, Andrabi SA, Lee JH, Meza-Perez S, Randall TD, et al. Mitochondrial calcium uniporter regulates PGC-1 $\alpha$ expression to mediate metabolic reprogramming in pulmonary fibrosis. Redox Biol. 2019;26:101307.

111. Deng M, Gui X, Kim J, Xie L, Chen W, Li Z, et al. LILRB4 signalling in leukaemia cells mediates T cell suppression and tumour infiltration. Nature. 2018;562:605-9.

112. Adiga D, Radhakrishnan R, Chakrabarty S, Kumar P, Kabekkodu SP. The role of calcium signaling in regulation of epithelial-mesenchymal transition. Cells Tissues Organs. Forthcoming 2021.

113. Leverrier-Penna S, Destaing O, Penna A. Insights and perspectives on calcium channel functions in the cockpit of cancerous space invaders. Cell Calcium. 2020;90:102251.

114. Bauer KS, Cude KJ, Dixon SC, Kruger EA, Figg WD. Carboxyamido-triazole inhibits angiogenesis by blocking the calcium-mediated nitric-oxide synthase-vascular endothelial growth factor pathway. J Pharmacol Exp Ther. 2000;292:31-7.

115. Almquist M, Anagnostaki L, Bondeson L, Bondeson AG, Borgquist S, Landberg G, et al. Serum calcium and tumour aggressiveness in breast cancer: a prospective study of 7847 women. Eur J Cancer Prev. 2009;18:354-60.

116. Li XC, Dong YY, Cheng Y, Zhou JY, Yang X, Shen BQ, et al. Increased serum calcium level promotes the risk of lymph node metastasis in endometrial cancer. Cancer Manag Res. 2020;12:5023-30.

117. Huang SY, Chen Y, Tan XR, Gong S, Yang XJ, He QM, et al. Serum calcium levels before antitumour therapy predict clinical outcomes in patients with nasopharyngeal carcinoma. Onco Targets Ther. 2020;13:13111-9.

118. Tsuji Y, Nakamori S, Ariyoshi H, Sakon M, Aono Y, Ueda A, et al. Cancer cell contact causes oscillatory and polarized rise of cytoplasmic ionized calcium concentration in human umbilical vein endothelial cells. Int J Oncol. 2002;21:541-6.

119. Wu D, Ma X, Lin F. DC electric fields direct breast cancer cell migration, induce EGFR polarization, and increase the intracellular level of calcium ions. Cell Biochem Biophys. 2013;67:1115-25.

120. Pon CK, Lane JR, Sloan EK, Halls ML. The $\beta_{2}$-adrenoceptor activates a positive cAMP-calcium feedforward loop to drive breast cancer cell invasion. FASEB J. 2016;30:1144-54. 
121. Hwang YP, Jeong HG. Metformin blocks migration and invasion of tumour cells by inhibition of matrix metalloproteinase-9 activation through a calcium and protein kinase Calpha-dependent pathway: phorbol-12-myristate-13-acetate-induced/extracellular signal-regulated kinase/activator protein-1. $\mathrm{Br}$ J Pharmacol. 2010;160:1195-211.

122. Timar J, Chopra H, Rong X, Hatfield JS, Fligiel SE, Onoda JM, et al. Calcium channel blocker treatment of tumor cells induces alterations in the cytoskeleton, mobility of the integrin alpha IIb beta 3 and tumorcell-induced platelet aggregation. J Cancer Res Clin Oncol. 1992;118:425-34.

123. Wang H, Gao X, Yang JJ, Liu ZR. Interaction between p68 RNA helicase and $\mathrm{Ca}^{2+}$-calmodulin promotes cell migration and metastasis. Nat Commun. 2013;4:1354.

124. Villalobo A, Berchtold MW. The role of calmodulin in tumor cell migration, invasiveness, and metastasis. Int J Mol Sci. 2020;21:765.

125. Liu Z, Han G, Cao Y, Wang Y, Gong H. Calcium/calmodulin-dependent protein kinase II enhances metastasis of human gastric cancer by upregulating nuclear factor- $\mathrm{\kappa B}$ and Akt-mediated matrix metalloproteinase- 9 production. Mol Med Rep. 2014;10:2459-64.

126. Sheng W, Wang G, Tang J, Shi X, Cao R, Sun J, et al. Calreticulin promotes EMT in pancreatic cancer via mediating $\mathrm{Ca}^{2+}$ dependent acute and chronic endoplasmic reticulum stress. J Exp Clin Cancer Res. 2020;39:209.

127. Grosshans HK, Fischer TT, Steinle JA, Brill AL, Ehrlich BE. Neuronal Calcium Sensor 1 is up-regulated in response to stress to promote cell survival and motility in cancer cells. Mol Oncol. 2020;14:1134-51.

128. Xie R, Xu J, Xiao Y, Wu J, Wan H, Tang B, et al. Calcium promotes human gastric cancer via a novel coupling of calcium-sensing receptor and TRPV4 channel. Cancer Res. 2017;77:6499-512.

129. Chan KT, Bennin DA, Huttenlocher A. Regulation of adhesion dynamics by calpain-mediated proteolysis of focal adhesion kinase (FAK). J Biol Chem. 2010;285:11418-26.

130. Zheng JC, Chang KJ, Jin YX, Zhao XW, Li B, Yang MH. Arsenic trioxide inhibits the metastasis of small cell lung cancer by blocking calcineurin-nuclear factor of activated T cells (NFAT) signaling. Med Sci Monit. 2019;25:2228-37.

131. Zhou X, Liu Y, You J, Zhang H, Zhang X, Ye L. Myosin light-chain kinase contributes to the proliferation and migration of breast cancer cells through cross-talk with activated ERK1/2. Cancer Letters. 2008;270:312-27.

132. Luu HH, Zhou L, Haydon RC, Deyrup AT, Montag AG, Huo D, et al. Increased expression of S100A6 is associated with decreased metastasis and inhibition of cell migration and anchorage independent growth in human osteosarcoma. Cancer Lett. 2005;229:135-48.

133. Li T, Yi L, Hai L, Ma H, Tao Z, Zhang C, et al. The interactome and spatial redistribution feature of $\mathrm{Ca}^{2+}$ receptor protein calmodulin reveals a novel role in invadopodia-mediated invasion. Cell Death Dis. 2018;9:292.

134. Joeckel E, Haber T, Prawitt D, Junker K, Hampel C, Thüroff JW, et al. High calcium concentration in bones promotes bone metastasis in renal cell carcinomas expressing calcium-sensing receptor. Mol Cancer. 2014;13:42.

135. Apasu JE, Schuette D, LaRanger R, Steinle JA, Nguyen LD, Grosshans HK, et al. Neuronal calcium sensor 1 (NCS1) promotes motility and metastatic spread of breast cancer cells in vitro and in vivo. FASEB J. 2019;33:4802-13.

136. Moriyama-Kita M, Endo Y, Yonemura Y, Heizmann CW, Miyamori H, Sato H, et al. S100A4 regulates E-cadherin expression in oral squamous cell carcinoma. Cancer Lett. 2005;230:211-8.

137. Jiao J, González Á, Stevenson HL, Gagea M, Sugimoto H, Kalluri R, et al. Depletion of S100A4+ stromal cells does not prevent HCC development but reduces the stem cell-like phenotype of the tumors. Exp Mol Med. 2018;50:e422. 
138. Wei R, Zhu WW, Yu GY, Wang X, Gao C, Zhou X, et al. S100 calcium-binding protein A9 from tumorassociated macrophage enhances cancer stem cell-like properties of hepatocellular carcinoma. Int J Cancer. 2020;148:1233-44.

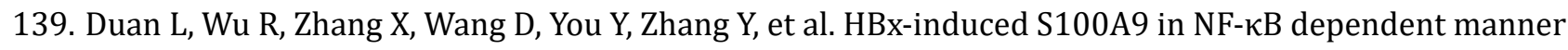
promotes growth and metastasis of hepatocellular carcinoma cells. Cell Death Dis. 2018;9:629.

140. Li N, Liu L, Li G, Xia M, Du C, Zheng Z. The role of BKCa in endometrial cancer HEC-1-B cell proliferation and migration. Gene. 2018;655:42-7.

141. Hu J, Yuan X, Ko MK, Yin D, Sacapano MR, Wang X, et al. Calcium-activated potassium channels mediated blood-brain tumor barrier opening in a rat metastatic brain tumor model. Mol Cancer. 2007;6:22.

142. Potier M, Chantome A, Joulin V, Girault A, Roger S, Besson P, et al. The SK3/K(Ca)2.3 potassium channel is a new cellular target for edelfosine. Br J Pharmacol. 2011;162:464-79.

143. Wu L, Lin W, Liao Q, Wang H, Lin C, Tang L, et al. Calcium channel blocker nifedipine suppresses colorectal cancer progression and immune escape by preventing NFAT2 nuclear translocation. Cell Rep. 2020;33:108327.

144. Hao J, Bao X, Jin B, Wang X, Mao Z, Li X, et al. $\mathrm{Ca}^{2+}$ channel subunit $\alpha$ 1D promotes proliferation and migration of endometrial cancer cells mediated by $17 \beta$-estradiol via the $G$ protein-coupled estrogen receptor. FASEB J. 2015;29:2883-93.

145. Jacquemet G, Baghirov H, Georgiadou M, Sihto H, Peuhu E, Cettour-Janet P, et al. L-type calcium channels regulate filopodia stability and cancer cell invasion downstream of integrin signalling. Nat Commun. 2016;7:13297.

146. Jin YM, Ye Y, Bao WQ Tong Y, Ni SB, Liu JP, et al. CACNA1B facilitates breast cancer cell growth and migration by regulating cyclin D1 and EMT: the implication of CACNA1B in breast cancer. J Recept Signal Transduct. Forthcoming 2021.

147. Zhang Y, Zhang J, Jiang D, Zhang D, Qian Z, Liu C, et al. Inhibition of T-type $\mathrm{Ca}^{2+}$ channels by endostatin attenuates human glioblastoma cell proliferation and migration. Br J Pharmacol. 2012;166:1247-60.

148. Maiques O, Barceló C, Panosa A, Pijuan J, Orgaz JL, Rodriguez-Hernandez I, et al. T-type calcium channels drive migration/invasion in BRAFV600E melanoma cells through Snail1. Pigment Cell Melanoma Res. 2018;31:484-95.

149. Leung CS, Yeung TL, Yip KP, Pradeep S, Balasubramanian L, Liu J, et al. Calcium-dependent FAK/CREB/ TNNC1 signalling mediates the effect of stromal MFAP5 on ovarian cancer metastatic potential. Nat Commun. 2014;5:5092.

150. Zhu M, Chen L, Zhao P, Zhou H, Zhang C, Yu S, et al. Store-operated $\mathrm{Ca}^{2+}$ entry regulates glioma cell migration and invasion via modulation of Pyk2 phosphorylation. J Exp Clin Cancer Res. 2014;33:98.

151. Goswamee P, Pounardjian T, Giovannucci DR. Arachidonic acid-induced $\mathrm{Ca}^{2+}$ entry and migration in a neuroendocrine cancer cell line. Cancer Cell Int. 2018;18:30.

152. Casas-Rua V, Tomas-Martin P, Lopez-Guerrero AM, Alvarez IS, Pozo-Guisado E, Martin-Romero FJ. STIM1 phosphorylation triggered by epidermal growth factor mediates cell migration. Biochim Biophys Acta. 2015;1853:233-43.

153. Xia J, Wang H, Huang H, Sun L, Dong S, Huang N, et al. Elevated Orai1 and STIM1 expressions upregulate MACC1 expression to promote tumor cell proliferation, metabolism, migration, and invasion in human gastric cancer. Cancer Lett. 2016;381:31-40.

154. Wu S, Chen M, Huang J, Zhang F, Lv Z, Jia Y, et al. ORAI2 promotes gastric cancer tumorigenicity and metastasis through PI3K/Akt signaling and MAPK-dependent focal adhesion disassembly. Cancer Res. 2020;81:986-1000.

155. Sun J, Lu F, He H, Shen J, Messina J, Mathew R, et al. STIM1- and Orai1-mediated $\mathrm{Ca}^{2+}$ oscillation orchestrates invadopodium formation and melanoma invasion. J Cell Biol. 2014;207:535-48. 
156. Koslowski M, Türeci O, Huber C, Sahin U. Selective activation of tumor growth-promoting $\mathrm{Ca}^{2+}$ channel MS4A12 in colon cancer by caudal type homeobox transcription factor CDX2. Mol Cancer. 2009;8:77.

157. Zhang LY, Zhang YQ, Zeng YZ, Zhu JL, Chen H, Wei XL, et al. TRPC1 inhibits the proliferation and migration of estrogen receptor-positive Breast cancer and gives a better prognosis by inhibiting the PI3K/AKT pathway. Breast Cancer Res Treat. 2020;182:21-33.

158. Oda K, Umemura M, Nakakaji R, Tanaka R, Sato I, Nagasako A, et al. Transient receptor potential cation 3 channel regulates melanoma proliferation and migration. J Physiol Sci. 2017;67:497-505.

159. Wei WC, Huang WC, Lin YP, Becker EBE, Ansorge O, Flockerzi V, et al. Functional expression of calciumpermeable canonical transient receptor potential 4-containing channels promotes migration of medulloblastoma cells. J Physiol. 2017;595:5525-44.

160. Chen Z, Zhu Y, Dong Y, Zhang P, Han X, Jin J, et al. Overexpression of TrpC5 promotes tumor metastasis via the HIF-1alpha-Twist signaling pathway in colon cancer. Clin Sci (Lond). 2017;131:2439-50.

161. Jardin I, Diez-Bello R, Lopez JJ, Redondo PC, Salido GM, Smani T, et al. TRPC6 channels are required for proliferation, migration and invasion of breast cancer cell lines by modulation of orai1 and orai3 surface exposure. Cancers (Basel). 2018;10:331.

162. Kim JH, Hwang KH, Eom M, Kim M, Park EY, Jeong Y, et al. WNK1 promotes renal tumor progression by activating TRPC6-NFAT pathway. FASEB J. 2019;33:8588-99.

163. Song Y, Liu G, Liu S, Chen R, Wang N, Liu Z, et al. Helicobacter pylori upregulates TRPC6 via Wnt/betacatenin signaling to promote gastric cancer migration and invasion. Onco Targets Ther. 2019;12:5269-79

164. Almasi S, Sterea AM, Fernando W, Clements DR, Marcato P, Hoskin DW, et al. TRPM2 ion channel promotes gastric cancer migration, invasion and tumor growth through the AKT signaling pathway. Sci Rep. 2019;9:4182.

165. Li W, Yang FQ Sun CM, Huang JH, Zhang HM, Li X, et al. circPRRC2A promotes angiogenesis and metastasis through epithelial-mesenchymal transition and upregulates TRPM3 in renal cell carcinoma. Theranostics. 2020;10:4395-409.

166. Gao Y, Liao P. TRPM4 channel and cancer. Cancer Lett. 2019;454:66-9.

167. Sagredo AI, Sagredo EA, Pola V, Echeverría C, Andaur R, Michea L, et al. TRPM4 channel is involved in regulating epithelial to mesenchymal transition, migration, and invasion of prostate cancer cell lines. J Cell Physiol. 2019;234:2037-50.

168. Maeda T, Suzuki A, Koga K, Miyamoto C, Maehata Y, Ozawa S, et al. TRPM5 mediates acidic extracellular pH signaling and TRPM5 inhibition reduces spontaneous metastasis in mouse B16-BL6 melanoma cells. Oncotarget. 2017;8:78312-26.

169. Meng X, Cai C, Wu J, Cai S, Ye C, Chen $\mathrm{H}$, et al. TRPM7 mediates breast cancer cell migration and invasion through the MAPK pathway. Cancer Lett. 2013;333:96-102.

170. Chen JP, Wang J, Luan Y, Wang CX, Li WH, Zhang JB, et al. TRPM7 promotes the metastatic process in human nasopharyngeal carcinoma. Cancer Lett. 2015;356:483-90.

171. Liu L, Wu N, Wang Y, Zhang X, Xia B, Tang J, et al. TRPM7 promotes the epithelial-mesenchymal transition in ovarian cancer through the calcium-related PI3K/AKT oncogenic signaling. J Exp Clin Cancer Res. 2019;38:106.

172. Liu JJ, Li LZ, Xu P. Upregulation of TRPM8 can promote the colon cancer liver metastasis through mediating Akt/GSK-3 signal pathway. Biotechnol Appl Biochem. Forthcoming 2021.

173. Lyu L, Jin X, Li Z, Liu S, Li Y, Su R, et al. TBBPA regulates calcium-mediated lysosomal exocytosis and thereby promotes invasion and migration in hepatocellular carcinoma. Ecotoxicol Environ Saf. 2020;192:110255.

174. Wu K, Shen B, Jiang F, Xia L, Fan T, Qin M, et al. TRPP2 enhances metastasis by regulating epithelialmesenchymal transition in laryngeal squamous cell carcinoma. Cell Physiol Biochem. 2016;39:2203-15. 
175. Gao N, Yang F, Chen S, Wan H, Zhao X, Dong H. The role of TRPV1 ion channels in the suppression of gastric cancer development. J Exp Clin Cancer Res. 2020;39:206.

176. Siveen KS, Nizamuddin PB, Uddin S, Al-Thani M, Frenneaux MP, Janahi IA, et al. TRPV2: a cancer biomarker and potential therapeutic target. Dis Markers. 2020;2020:8892312.

177. Li X, Cheng Y, Wang Z, Zhou J, Jia Y, He X, et al. Calcium and TRPV4 promote metastasis by regulating cytoskeleton through the RhoA/ROCK1 pathway in endometrial cancer. Cell Death Dis. 2020;11:1009.

178. Lee WH, Choong LY, Jin TH, Mon NN, Chong S, Liew CS, et al. TRPV4 plays a role in breast cancer cell migration via $\mathrm{Ca}^{2+}$-dependent activation of AKT and downregulation of E-cadherin cell cortex protein. Oncogenesis. 2017;6:e338.

179. Cappelli HC, Kanugula AK, Adapala RK, Amin V, Sharma P, Midha P, et al. Mechanosensitive TRPV4 channels stabilize VE-cadherin junctions to regulate tumor vascular integrity and metastasis. Cancer Lett. 2019;442:15-20.

180. Chen Y, Liu X, Zhang F, Liao S, He X, Zhuo D, et al. Vitamin D receptor suppresses proliferation and metastasis in renal cell carcinoma cell lines via regulating the expression of the epithelial $\mathrm{Ca}^{2+}$ channel TRPV5. PLoS One. 2018;13:e0195844.

181. Raphaël M, Lehen'kyi V, Vandenberghe M, Beck B, Khalimonchyk S, Vanden Abeele F, et al. TRPV6 calcium channel translocates to the plasma membrane via Orai1-mediated mechanism and controls cancer cell survival. Proc Natl Acad Sci U S A. 2014;111:E3870-9.

182. Wang T, Li N, Jin L, Qi X, Zhang C, Hua D. The calcium pump PMCA4 prevents epithelial-mesenchymal transition by inhibiting NFATc1-ZEB1 pathway in gastric cancer. Biochim Biophys Acta Mol Cell Res. 2020;1867:118833.

183. Ryu S, McDonnell K, Choi H, Gao D, Hahn M, Joshi N, et al. Suppression of miRNA-708 by polycomb group promotes metastases by calcium-induced cell migration. Cancer Cell. 2013;23:63-76.

184. Chung FY, Lin SR, Lu CY, Yeh CS, Chen FM, Hsieh JS, et al. Sarco/endoplasmic reticulum calcium-ATPase 2 expression as a tumor marker in colorectal cancer. Am J Surg Pathol. 2006;30:969-74.

185. Gou WF, Niu ZF, Zhao S, Takano Y, Zheng HC. Aberrant SERCA3 expression during the colorectal adenomaadenocarcinoma sequence. Oncol Rep. 2014;31:232-40.

186. Brisson L, Chadet S, Lopez-Charcas O, Jelassi B, Ternant D, Chamouton J, et al. P2X7 receptor promotes mouse mammary cancer cell invasiveness and tumour progression, and is a target for anticancer treatment. Cancers (Basel). 2020;12:2342.

187. Zhang WJ, Hu CG, Luo HL, Zhu ZM. Activation of P2X7 receptor promotes the invasion and migration of colon cancer cells via the STAT3 Signaling. Front Cell Dev Biol. 2020;8:586555.

188. Zhang Y, Cheng H, Li W, Wu H, Yang Y. Highly-expressed P2X7 receptor promotes growth and metastasis of human HOS/MNNG osteosarcoma cells via PI3K/Akt/GSK3 $\beta / \beta$-catenin and mTOR/HIF1 $\alpha /$ VEGF signaling. Int J Cancer. 2019;145:1068-82.

189. Chen L, He HY, Li HM, Zheng J, Heng WJ, You JF, et al. ERK1/2 and p38 pathways are required for P2Y receptor-mediated prostate cancer invasion. Cancer Lett. 2004;215:239-47.

190. Li WH, Qiu Y, Zhang HQ, Liu Y, You JF, Tian XX, et al. P2Y2 receptor promotes cell invasion and metastasis in prostate cancer cells. Br J Cancer. 2013;109:1666-75.

191. Girard M, Dagenais Bellefeuille S, Eiselt É, Brouillette R, Placet M, Arguin G, et al. The P2Y ${ }_{6}$ receptor signals through $\mathrm{G} \alpha_{\mathrm{q}} / \mathrm{Ca}^{2+} / \mathrm{PKC} \alpha$ and $\mathrm{G} \alpha_{13} / \mathrm{ROCK}$ pathways to drive the formation of membrane protrusions and dictate cell migration. J Cell Physiol. 2020;235:9676-90.

192. Kamiyama M, Shirai T, Tamura S, Suzuki-Inoue K, Ehata S, Takahashi K, et al. ASK1 facilitates tumor metastasis through phosphorylation of an ADP receptor P2 $\mathrm{Y}_{12}$ in platelets. Cell Death Differ. 2017;24:2066-76. 
193. Chen L, Sun Q, Zhou D, Song W, Yang $Q$ Ju B, et al. HINT2 triggers mitochondrial $\mathrm{Ca}^{2+}$ influx by regulating the mitochondrial $\mathrm{Ca}^{2+}$ uniporter (MCU) complex and enhances gemcitabine apoptotic effect in pancreatic cancer. Cancer Lett. 2017;411:106-16.

194. Ren T, Zhang H, Wang J, Zhu J, Jin M, Wu Y, et al. MCU-dependent mitochondrial Ca ${ }^{2+}$ inhibits $\mathrm{NAD}^{+} / \mathrm{SIRT}_{\text {/ }}$ SOD2 pathway to promote ROS production and metastasis of HCC cells. Oncogene. 2017;36:5897-909.

195. Zheng X, Lu S, He Z, Huang H, Yao Z, Miao Y, et al. MCU-dependent negative sorting of miR-4488 to extracellular vesicles enhances angiogenesis and promotes breast cancer metastatic colonization. Oncogene. 2020;39:6975-89.

196. Tosatto A, Sommaggio R, Kummerow C, Bentham RB, Blacker TS, Berecz T, et al. The mitochondrial calcium uniporter regulates breast cancer progression via HIF-1 $\alpha$. EMBO Mol Med. 2016;8:569-85.

197. Jin M, Wang J, Ji X, Cao H, Zhu J, Chen Y, et al. MCUR1 facilitates epithelial-mesenchymal transition and metastasis via the mitochondrial calcium dependent ROS/Nrf2/Notch pathway in hepatocellular carcinoma. J Exp Clin Cancer Res. 2019;38:136.

198. D’Amore A, Hanbashi AA, Di Agostino S, Palombi F, Sacconi A, Voruganti A, et al. Loss of two-pore channel 2 (TPC2) expression increases the metastatic traits of melanoma cells by a mechanism involving the hippo signalling pathway and store-operated calcium entry. Cancers (Basel). 2020;12:2391.

199. Shibao K, Fiedler MJ, Nagata J, Minagawa N, Hirata K, Nakayama Y, et al. The type III inositol 1,4,5-trisphosphate receptor is associated with aggressiveness of colorectal carcinoma. Cell calcium. 2010;48:315-23.

200. Xu N, Zhang D, Chen J, He G, Gao L. Low expression of ryanodine receptor 2 is associated with poor prognosis in thyroid carcinoma. Oncol Lett. 2019;18:3605-12.

201. Cui C, Chang Y, Zhang X, Choi S, Tran H, Penmetsa KV, et al. Targeting Orai1-mediated store-operated calcium entry by RP4010 for anti-tumor activity in esophagus squamous cell carcinoma. Cancer Lett. 2018;432:169-79.

202. Yu C, Tang W, Wang Y, Shen Q, Wang B, Cai C, et al. Downregulation of ACE2/Ang-(1-7)/Mas axis promotes breast cancer metastasis by enhancing store-operated calcium entry. Cancer Lett. 2016;376:268-77.

203. Li J, McKeown L, Ojelabi O, Stacey M, Foster R, O'Regan D, et al. Nanomolar potency and selectivity of a $\mathrm{Ca}^{2+}$ release-activated $\mathrm{Ca}^{2+}$ channel inhibitor against store-operated $\mathrm{Ca}^{2+}$ entry and migration of vascular smooth muscle cells. Br J Pharmacol. 2011;164:382-93.

204. Hammadi M, Chopin V, Matifat F, Dhennin-Duthille I, Chasseraud M, Sevestre $H$, et al. Human ether à-gogo $\mathrm{K}^{+}$channel 1 (hEag1) regulates MDA-MB-231 breast cancer cell migration through Orai1-dependent calcium entry. J Cell Physiol. 2012;227:3837-46.

205. Zhang X, Zhang L, Lin B, Chai X, Li R, Liao Y, et al. Phospholipid Phosphatase 4 promotes proliferation and tumorigenesis, and activates $\mathrm{Ca}^{2+}$-permeable Cationic Channel in lung carcinoma cells. Mol Cancer. 2017;16:147.

206. Gershkovitz M, Caspi Y, Fainsod-Levi T, Katz B, Michaeli J, Khawaled S, et al. TRPM2 mediates neutrophil killing of disseminated tumor cells. Cancer Res. 2018;78:2680-90.

207. Kanugula AK, Adapala RK, Midha P, Cappelli HC, Meszaros JG, Paruchuri S, et al. Novel noncanonical regulation of soluble VEGF/VEGFR2 signaling by mechanosensitive ion channel TRPV4. FASEB J. 2019;33:195-203.

208. Cui C, Yang J, Fu L, Wang M, Wang X. Progress in understanding mitochondrial calcium uniporter complexmediated calcium signalling: a potential target for cancer treatment. Br J Pharmacol. 2019;176:1190-205.

209. Gu L, Larson-Casey JL, Carter AB. Macrophages utilize the mitochondrial calcium uniporter for profibrotic polarization. FASEB J. 2017;31:3072-83.

210. Fouque A, Lepvrier E, Debure L, Gouriou Y, Malleter M, Delcroix V, et al. The apoptotic members CD95, $\mathrm{BclxL}$, and $\mathrm{Bcl}-2$ cooperate to promote cell migration by inducing $\mathrm{Ca}^{2+}$ flux from the endoplasmic reticulum to mitochondria. Cell Death Differ. 2016;23:1702-16. 
211. Ndiaye D, Collado-Hilly M, Martin J, Prigent S, Dufour JF, Combettes L, et al. Characterization of the effect of the mitochondrial protein Hint2 on intracellular $\mathrm{Ca}^{2+}$ dynamics. Biophys J. 2013;105:1268-75.

212. Davis FM, Parsonage MT, Cabot PJ, Parat MO, Thompson EW, Roberts-Thomson SJ, et al. Assessment of gene expression of intracellular calcium channels, pumps and exchangers with epidermal growth factorinduced epithelial-mesenchymal transition in a breast cancer cell line. Cancer Cell Int. 2013;13:76.

213. Kang S, Hong J, Lee JM, Moon HE, Jeon B, Choi J, et al. Trifluoperazine, a well-known antipsychotic, inhibits glioblastoma invasion by binding to calmodulin and disinhibiting calcium release channel $\mathrm{IP}_{3} \mathrm{R}$. Mol Cancer Ther. 2017;16:217-27. 